Illinois State University

ISU ReD: Research and eData

Theses and Dissertations

$11-21-2013$

\title{
Citizens Without a Nation: The Construction of Haitian Illegality and Deportability in the Dominican Republic
}

Sasha Miranda

Illinois State University, smirandadrv@gmail.com

Follow this and additional works at: https://ir.library.illinoisstate.edu/etd

Part of the Sociology Commons

\section{Recommended Citation}

Miranda, Sasha, "Citizens Without a Nation: The Construction of Haitian Illegality and Deportability in the Dominican Republic" (2013). Theses and Dissertations. 147.

https://ir.library.illinoisstate.edu/etd/147

This Thesis is brought to you for free and open access by ISU ReD: Research and eData. It has been accepted for inclusion in Theses and Dissertations by an authorized administrator of ISU ReD: Research and eData. For more information, please contact ISUReD@ilstu.edu. 


\title{
CITIZENS WITHOUT A NATION:
}

\section{THE CONSTRUCTION OF HAITIAN ILLEGALITY AND DEPORTABILITY IN THE DOMINICAN REPUBLIC}

\author{
Sasha Miranda
}

118 Pages

May 2014

Migrant "illegality" has increasingly become a popular topic in political debates around the world, but illegal populations are not random or self-generating, they are created and patterned (DeGenova 2002:422). Through the recent enforcement of new and existing immigration laws, the Dominican State has begun to move large populations of Haitian immigrants and their descendants into irregular or "illegal" immigration status.

A historical analysis of the relationship between the Dominican State and Haitian immigrants presents a paradox: the Dominican economy has become increasingly dependent on Haitian migrant labor, yet the Dominican State has persistently worked to force Haitians and their descendants into irregular migratory status. The irregular immigration status leaves these individuals vulnerable and in a constant state of deportability.

This research makes two claims in an attempt to understand the motives of the state; primarily, the Dominicans State has used immigration policy to assert its territorial sovereignty and enforce the historically embedded ideology of anti-Haitianism. Secondly, the Dominican State has used immigration policy and immigration enforcement to 
control and subordinate a large Haitian workforce. The research takes an interpretive hermeneutic approach to conduct an in-depth historical analysis of five key pieces of Dominican legislation, which comprise the recent Dominican immigration reform. This analysis is conducted though drawing on the economic, historical, and social information characterizing the relationship between the State and Haitian immigrants. These analytical tools are combined with the personal experiences of the researcher.

The investigation relies primarily on theoretical literature of Nicholas DeGenova to conclude that the state uses nationalistic ideas to maintain support for the irregular status of Haitian immigrants and their descendants. The irregular and thus deportable status of Haitian immigrants and their descendants is functional to the Dominican capitalist economic system. 


\section{CITIZENS WITHOUT A NATION: \\ THE CONSTRUCTION OF HAITIAN ILLEGALITY AND DEPORTABILITY IN THE DOMINICAN REPUBLIC}

SASHA MIRANDA

A Thesis Submitted in Partial Fulfillment of the Requirements for the Degree of MASTER OF ARTS

Department of Sociology

ILLINOIS STATE UNIVERSITY 
Copyright 2014 Sasha Miranda 


\section{CITIZENS WITHOUT A NATION: \\ THE CONSTRUCTION OF HAITIAN ILLEGALITY AND DEPORTABILITY IN THE DOMINICAN REPUBLIC}

SASHA MIRANDA

COMMITTEE MEMBERS

Maura Toro-Morn, Chair

Richard Sullivan

Carlos Parodi 


\section{ACKNOWLEDGEMENTS}

I would like to acknowledge the support and assistance from my thesis committee: Dr. Parodi, Dr. Sullivan, and especially to my chair, Dr. Toro-Morn. Dr. Toro-Morn, I cannot thank you enough. You have been an amazing source of encouragement and support the last couple of years. I am grateful for your endless patience, kindness, enthusiasm and encouragement. Thank you for always sharing your time and insights with me, and always making me feel worthy of it and like family.

I would also like to thank Beverly Beyer and Frank Beck of the Stevenson Center. Thank you for always checking in on me, sending care packages, and believing that I could do this. Lastly, I would also like to express my appreciation for my Dominican community, Barrio Filiu, especially my host family. Thank you for sharing your home and your heart with me and for helping me learn so much about Dominican and Haitian culture, life, love and a true sense of community. 


\section{CONTENTS}

CONTENTS

\section{CHAPTER}

I .OVERVIEW OF THE RESEARCH 1

Statement of the problem $\quad 4$

$\begin{array}{ll}\text { Research Objectives } & 6\end{array}$

II. REVIEW OF RELEVANT LITERATURE 8

$\begin{array}{ll}\text { Historical Analysis } & 8\end{array}$

Antihaitianismo 9

The Indio Myth 11

Colonial Racial Formations $\quad 13$

Haitian Revolution $\quad 16$

Haitian Occupation $\quad 17$

Outside Influences on Antihaitianismo 20

Trujillo and Dominicanidad 21

Neo-Antihaitianismo 23

$\begin{array}{ll}\text { Theoretical Literature } & 25\end{array}$

Nation-State Sovereignty 25

Conceptualizing Citizenship $\quad 28$

Fetishization of Illegality 33

Border Spectacle 36

Deportability 38 
Haitian Immigration History $\quad 40$

Bracero Program 41

The "New Migration" 43

Haitian Profile 46

First National Study of Immigrants 47

Size of the Haitian Population in the Dominican Republic 47

Economic Impact of Haitian Migrant Labor 50

$\begin{array}{ll}\text { IV.METHODOLOGY } & 55\end{array}$

Analytical Tools $\quad 56$

Hermeneutic Analysis $\quad 56$

Historical Analysis $\quad 57$

Experience of the Researcher $\quad 57$

Research Design $\quad 59$

Data Collection $\quad 60$

Process of Analysis 61

V. ANALYSIS OF THE DATA 63

Analysis of Migration Law 95 of 1939 and Regulations and

Procedures 279

How is Legal Status Constructed? 64

Migrant Illegality and Deportability 66

In-transit Clause $\quad 66$

Migrant Labor $\quad 67$

$\begin{array}{ll}\text { Summary } & 68\end{array}$

Analysis of General Migration Law 285-04 and

Regulation and Procedures 631 69

How is Legal Status Constructed? $\quad 70$

Migrant Illegality and Deportability $\quad 72$

In-transit Clause $\quad 75$

Migrant Labor $\quad 76$ 
Analysis of the Legislative Build-up to Sentence 0168-13 81

$\begin{array}{ll}\text { Jus Soli Citizenship } & 82\end{array}$

Yean and Bosico vs the Dominican Republic $\quad 84$

Resolution 12-07 and Circular $017 \quad 86$

$\begin{array}{ll}\text { Constitution Change } & 88\end{array}$

Analysis of Constitutional Court Sentence 0168-13 89

Nation-State Sovereignty $\quad 90$

Haitian Invasion? 93

Basis for the Rejection of Nationality 94

VI. DISCUSSION, CONCLUSIONS AND RECOMMENDATIONS 96

$\begin{array}{ll}\text { Discussion } & 96\end{array}$

Cornelisse and DeGenova 96

Dominican Nation-State Sovereignty 97

Denaturalizing Haitian Migrant Illegality 99

The Border Spectacle $\quad 100$

Citizenship and Ideological Borders 103

$\begin{array}{ll}\text { Conclusions } & 105\end{array}$

Increasing Awareness of the Haitian Population? 105

Useful Distraction? 108

Political Scheme? 109

Limitations and Contributions of the Research 111

Limitations of the Research 111

Contributions of the Research 112

$\begin{array}{ll}\text { REFERENCES } & 114\end{array}$ 


\section{CHAPTER I}

\section{OVERVIEW OF THE RESEARCH}

On October $2^{\text {nd }}$ of 1937 both Dominicans and Haitians were exposed to the depths of the brutality and ruthlessness of the Dominican Dictator Rafael Leonidas Trujillo and the national ideology of antihaitianismo (anti-Haitianism). On this day the dictator ordered the five day massacre of an estimated 20,000 Haitians and their descendants living on the Dominican-Haitian border. The massacre is also known as El Corte (the cutting), as Trujillo ordered that the massacre be carried out mainly with the use of machetes and bayonets. The Dictator avoided the use of guns in an attempt to portray the massacre to the Dominican public and internationally as a civil uprising, caused by the frustration of Dominicans with Haitian cattle and land thieves (Moya-Pons 1995).

While the massacre could have been politically damaging for the Dictator, Trujillo managed to successfully organize the government, the press, and the intelligentsia to propagate the image of Trujillo as the "Defender of the Dominican Nation" (Martinez 1999:70). The massacre became a springboard for the administration to begin directing attention from the atrocities committed and diverting it to the "Haitian menace to the Dominican race" (Martinez 1999:70). The Haitian presence in the Dominican Republic was described in apocalyptic terms: Haitians had a clandestine plan 
to unite the island like during the 22 year occupation; they would Africanize and contaminate the Dominican race; their presence was detrimental and damaging to Dominican society (Wooding and Moseley-Williams 2004).

Trujillo's motives behind the massacre were two-fold: primarily to Dominicanize the borders and expand Trujillo's rule over the rural and borderland areas through the militarization of the borders (Moya-Pons 1995). Secondly the massacre was part of a greater project of modernization of the Dominican state; cultural and racial homogeneity were important concerns for Trujillo and were also instrumental to his primary goal of making a political space for himself and consolidating political power over the entire country (Turits 2002).

Seventy- six years later, on September $23^{\text {rd }}$ of 2013 , Dominicans, Haitians and their descendants suffered another dark shock reminiscent of Trujillo Era antihaitianismo. The highest court in the territory, the Constitutional Court of the Dominican Republic passed Sentence 0168-13. The Sentence states that all individuals born to mothers of irregular immigration status as ineligible for Dominican birth-right citizenship. The Sentence calls for a retroactive investigation and subsequent stripping of citizenship from the descendants of irregular immigrants dating all the way back to 1929 .

This means that individuals who were declared as citizens all their lives could now potentially lose their citizenship status. The implications of the Sentence means that potentially 200,000 individuals could lose the right to enjoy the Dominican citizenship they have enjoyed their entire lives, due to the irregular migratory status of their parents, grand or maybe even great grandparents. 
The individuals implicated in the Sentence have lived all of their lives in the Dominican Republic, and consider themselves Dominican with little to no connection with Haiti. These individuals are now left in an ambiguous state of nationality, while all of their civil rights and privileges will be revoked.

The rhetoric accompanying the Constitutional Court Sentence has the same tone as the rhetoric used during the 1937 massacre, but now it has a legal basis: the State has the right to decide its social and cultural make-up, Haitians have fraudulently and illegally acquired Dominican citizenship, they are transgressors of the state, and they have violated the system.

The purpose of juxtaposing these two events is not to compare the levels of atrocity, but rather to highlight the role that antihaitianismo has played in re-establishing state political power and authority throughout history. Both of these events aid in illustrating the story of how the state has historically flexed its muscle of nation-state sovereignty to control and oppress Haitians within the Dominican Republic, while using the deep historically entrenched Dominican ideology of antihaitianismo or AntiHaitianism to garner popular support.

This research is an in-depth historical case study that seeks to explore the legal production of Haitian migrant illegality and deportability in the Dominican Republic. The main source of data in this study consists of an analysis of five key pieces of legislation within the Dominican immigration reform. The analysis of the legal documentation is contextualized and informed by a historical and economic analysis which outlines the dynamic between the Dominican state and Haitians immigrants; the history of Haitian 
immigration to the Dominican Republic; and the economic impact of Haitian migrant labor to the Dominican economy.

In addition to the contextual information, the analysis is also informed by the time I have spent as a researcher in the field. I have spent the last three years serving in the United States Peace Corps in the Dominican Republic. My experiences and relationships with Dominicans, Haitians, and Dominicans of Haitian descent, along with my time in the country have influenced the development of the research as well as the analysis of the data.

The theoretical literature constructs the framework for the interpretation and discussion of the analysis of the study. The theoretical framework is constructed using Nicholas DeGenova's theory of immigration legislation as a form of state control and labor subordination which is accomplished through the maintenance of migrant deportability. The theoretical literature of DeGenova is complemented by theoretical discussions on the concepts of nation-state sovereignty and citizenship.

The development of these theoretical concepts work in conjunction with the historical analysis is to develop a lens or hermeneutic tools through which the research interprets and understands the legal actions of the State.

\section{Statement of the Problem}

In the middle of the $20^{\text {th }}$ century the Dominican state had facilitated large bilateral labor contracts in collaboration with the Haitian government to facilitate the fluid and constant movement of as many as 12,000 to 20,000 Haitian migrant workers annually cross the border and into the developing sugar industry in the Dominican Republic (Martinez 1999). Since then the Dominican Republic has consistently relied on the 
availability of cheap Haitian labor to bolster the economy. The result of these large migrant mobilizations has been the development of a large permanent population of Haitian migrant workers and their descendants within the Dominican Republic.

Before a constitutional change in 2010, Article 11 of the Dominican Constitution granted all individuals born in the Dominican Republic jus soli or right of the soil citizenship. The exception to this rule were children born to individuals "in-transit", which at time of the clause's inception in 1939, "in- transit" was interpreted as diplomats and those who would be passing through the country for a period of ten days or less (Bartlett, Jayaram, and Bonhomme 2011; Wooding and Moseley-Williams 2004). Under this Constitutional determination of citizenship, many migrant Haitian workers registered their children as Dominican citizens, and these individuals have until recently enjoyed the conditions of citizenship.

Between the period of 2004 and 2010 the Dominican Republic unrolled a series of different legislative acts targeting Haitians and their descendants, which was comprised of new laws, internal memorandums, a change to the Constitution, and ultimately the Constitutional Court sentence 168-13. This series of legislation has constituted the most comprehensive reform of Dominican immigration statutes in 69 years (Open Society Justice Initiative 2009). This immigration reform has redefined the parameters of citizenship and migrant illegality for Haitians and Dominicans of Haitian descent.

Despite the reform of legislation regarding Haitian immigration status, Haitian labor has steadily become a structural and economic necessity in the Dominican Republic. Haitian labor represents more than $65 \%$ of agricultural labor force in four of the important agricultural sectors in the Dominican Republic (coffee, rice, sugar, and 
banana); approximately $90 \%$ of these Haitian migrant workers are undocumented (Centro de Formación y Agraría y Consultores Económicos Finacieros y Organizacionales 2012) (CEFASA/CEFINOSA).

The sectors that most rely on Haitian labor have experienced a 118\% growth increase between the years of 2006 and 2010 (CEFASA/CEFINOSA 2012:144). Despite this information the Dominican government has continued to fail to develop an immigration policy commensurate with international standards.

The relationship between Haitian immigrants and the Dominican state represent a paradox: the Dominican economy has become increasingly reliant on Haitian labor; yet the State has progressively taken legal action to keep these individuals in a perpetual state of irregular migratory status. Haitian laborers play an integral role in the economy, yet they are politically, socially and now legally portrayed as unwanted and live in a constant state of deportability.

The tenuous history between Dominicans and Haitian immigrants coupled with the Dominican ethno-racial identity that negates African heritage has informed the popular consensus that the immigration reform is a racist and discriminatory move on the part of the Dominican state. While race and discrimination play a role in the State's management of the Haitian population, viewing this phenomenon in this light may obscure the economic dimension of the Dominican- Haitian relationship.

\section{$\underline{\text { Research Objectives }}$}

Based on the problem outlined above, this research will be conducted under my assertion that the Dominican state has worked to create a large population of deportable immigrants for two main reasons. Primarily, as Haitian immigration has diversified and 
increased within Dominican society the Dominicans state has used the historically embedded national ideology of antihaitianismo to justify the implementation of Haitian targeted immigration policy. Secondly, the Dominican state has used immigration policy and enforcement to create and control a large Haitian workforce. The Dominican state has capitalized on its ability to restrict the rights and mobility of Haitian migrant workers, insuring the cheap sale of their labor within the Dominican market.

The overarching objective of the research is to examine these substantiate my assertions of the Dominican immigration reform through an analysis of the historical and legal production of Haitian illegality and deportability. This analysis will be contextualized within the historical relationship between Dominicans and Haitian immigrants and the economic significance of Haitian labor for the Dominican economy. I endeavor to provide preliminary insights into the motivation of the Dominican state in creating a large deportable population of Haitians and their descendants, which extend beyond xenophobic or racist conclusions. 


\section{CHAPTER II \\ REVIEW OF RELEVANT LITERATURE}

The following chapter is divided into two main parts: the first section is an indepth historical review of the relationship between the Dominican state and Haitian immigrants. An analysis of this issue helps construct a lens through which we can understand immigration issues today; according to Anthony Giddens (1967), “All understanding demands some measure of pre-understanding whereby further understanding is possible" (p. 63).

The second section of the chapter is dedicated to a review of the relevant theoretical literature and the development of a theoretical framework.

\section{$\underline{\text { Historical Analysis }}$}

Recent studies have demonstrated that there is a dynamic connection between legal status and social constructions: the production of legislation is mediated through other social and economic mechanisms (Donato and Arementa 2011:537). The Haitian presence in the Dominican Republic has constituted one of the most contentious social and political issues throughout Dominican history (Sillé 2005). The negative social construction of the Haitian presence in the Dominican Republic informs the construction of legislation and social policy. These social constructions have had a long period of development from the colonial period to the present. 


\section{Antihaitianismo}

The small island of Hispaniola is shared between the two nations of Haiti and the Dominican Republic; despite their proximity, these two nations have developed very different cultures, languages, and collective identities. The connected histories between the two countries has been marked by periods of both conflict and cooperation from the colonial period to the present; yet the relationship is most frequently described as contentious. The contention, at least from the Dominican side, is encapsulated in the Dominican ideology of antihaitianismo.

Directly translated antihaitianismo means anti-Haitianism, but the concept of antihaitianismo is more complex than a rejection of Haiti and Haitians as the English translation alludes. Antihaitianismo is an ideological package of beliefs that essentializes the differences between Dominicans and Haitians, and positions Dominicans as the racial and cultural superior to Haitians. Through the lens of Antihaitianismo, Dominicans are white, have Hispanic roots and Catholic beliefs; whereas Haitians are "invariably perceived as black, heathen and alien to white Spanish dominicanidad or Dominicanness. Haiti in popular prejudice, stands for all that is allegedly not Dominican: negritude, Africa, and non-Christian beliefs" (Howard 2001:5).

Antihaitianismo is like a coin whose other side is dominicanidad, which directly translated means Dominicanness: the characteristics of what it means to be Dominican. Dominicanidad is a collective identity that is formed through the juxtaposition between Dominicans and Haitians: Dominicans are from Hispanic heritage, while Haitians are Africans; Dominicans represent whiteness, Haitians blackness; and Dominicans uphold Christian values and beliefs while Haitians represent voodoo and pagan beliefs (Sagás 
2000). Dominicanidad is a national identity, one which results in the scorn and rejection of Haitians and Haitian culture, while identifying Haitians as invaders and culturally infectious (Howard 2001).

Apart from the racial and cultural aspects of antihaitianismo, another important component of the ideology is the belief that Haitians have the desire to reoccupy the Dominican Republic and unify the two sides of the island as was the case during the twenty- two year Haitian occupation of the Dominican Republic (Sagás 2000). Many politicians and important figures throughout Dominican history, especially the thirty year Dominican Dictator ,Rafael Leonidas Trujillo and his successor Joaquin Balaguer, have proposed that Haitian migration is part of a "passive invasion", where Haitians will take over the Dominican Republic and deteriorate Dominican culture (Sagás 2000).

Antihaitianismo has had a long period of development stemming from the colonial period to the present, punctuated with events and actors that have fortified the ideology and helped it remain a mainstay of Dominican culture. According to sociologist Ernesto Sagás (2001) antihaitianismo "combines a legacy of racist Spanish colonial mentality, nineteenth-century racial theories, and twentieth-century cultural neo-racism into a web of anti-Haitian attitudes, racial stereotypes, and historical distortions" (p.1).

The Dominican - Haitian immigrant relationship, analyzed from the Dominican perspective, demonstrates that many historical events and actors have perpetuated antihaitianismo ideology, making it a part of Dominican national identity. Dominicans have come to identify themselves vis-à-vis Haitians, this construction of Dominican national identity provides insight into the State's justification and motive behind the retroactive stripping of citizenship from Haitian descendants. 
In discussions regarding the Dominican Republic and Haitian immigrants, racial discrimination and degree of blackness between the two populations are often the most popular topics regarding Dominican-Haitian relations and is considered the basis for the revocation of citizenship for Haitian and Dominicans of Haitian descent.

While race is an important aspect of the antihaitianismo ideology, the concept of race in the Dominican Republic contains a whole host of historical and social markers, and therefore falls short of explaining the relationship of Dominicans and Haitian immigrant relationships alone. I will attempt to review race as a part of the ideological package of antihaitianismo, highlighting the struggle that Dominicans face with their own African past and identity, which then complicates their relationship to their "darker" more "African" Haitian neighbors.

\section{The Indio Myth}

The arrival of African slaves to both sides of Hispaniola in the $16^{\text {th }}$ century marked the beginning of the African presence in the in the western hemisphere; the legacy of the African presence lives through the skin color and cultural remnants on both sides of the island today (Torres-Saillant 2000). Despite this history the Dominican Republic holds a racial attitude that repudiates blackness, and upholds its indigenous history to explicate the accusation of being African descendants. From the perspective of academic observers, racially the Dominican Republic is classified as a mulatto society, with as much as $90 \%$ composed of blacks or mulattos, "yet no other country in the hemisphere exhibits greater indeterminacy regarding the population's sense of racial identity" (Torres-Saillant 2000:1086). 
The negation of African heritage in both elite and popular culture contrasted with the actual hue of the Dominican population required Dominicans to confront the reality of their skin color and create an ethno-racial identity that would fit their Afrophobic ideology (Candelario 2007, Howard 2001). In an effort to mitigate the actual skin color of its population, the Dominican Republic has constructed a socio- racial identity that classifies Dominicans as racially indigenous and culturally Hispanic, which allows for the devaluation of possible African influences in Dominican race or culture (Candelario 2007, Howard 2001).

The exaltation of indigenous past comes from the romanticized story of the Taíno Indian cacique Enriquillo who rebelled against the Spanish by liberating slaves from plantations and leading an Indian revolt in 1522 (Moya-Pons 1995). The story of Enriquillo was immortalized through the novel Enriquillo written by Manuel de Jesus Galván in 1882 which classified Dominicans as Indo-Hispanics; this presented a new ethno-racial option for Dominican national racial identity. According to Ernesto Sagás (2000), the Indio myth is "the most important ethnic fabrication developed in the late nineteenth century- and remains influential to this day" (p. 36).

While Dominicans may identify with indigenous roots as a main component of their racial make-up it is unlikely that this is actually the case. The indigenous population was eradicated much quicker than in other Latin American countries, and by the $17^{\text {th }}$ century only a very small population of Taíno Indians remained (Howard 2001). Despite the historical evidence to the contrary, the Indio myth has become an integral part of Dominican racial identity and has been propagated through school textbooks, the press and political discourse (Howard 2001:46). This notion has had many powerful 
proponents including the Dictator Rafael Leonidas Trujillo, and today the Indio myth is still alive through the institutionalization of racial identification on the government issued identity card, where most individuals will be labeled Indio under the race requirement. One of the main objectives of this myth is to separate the Dominican Republic from Haiti and African heritage and to legitimize racial prejudice (Howard 2001).

\section{Colonial Racial Formations}

Silvio Torres-Saillant (2000) proposes that "Dominicans of African descent possess what one might call a deracialized social consciousness whose origins date back to the fall of the plantation economy in colonial times" (1094). Torres-Saillant is among many other scholars have also attributed the motivation for the Dominican socio-ethnic construction of race to the different colonial economies and thus the different relationships between colonizers and colonized in the Dominican Republic and Haiti (Candelario 2007; Howard 2001; Moya-Pons 1995; Torres-Saillant 2000; Wucker 1999).

The colonial history presents a picture where different colonial economies and circumstances caused the phenotypic differences on either side of the island, while the relationships with outside entities influenced the Dominican self-identification as a rejection of its "blacker" Haitian neighbor. Dominican notions of racial identity are not classified within a white black dichotomy, but rather a Haitian/Dominican dichotomy. According to Torres-Saillant (2000) "Black Dominicans do not see blackness as the central component of their identity but tend to privilege their nationality instead, which implies participation in a culture, a language community, and the sharing of a lived experience" (p.1090). 
In 1867 the Treaty of Ryswick split the Island of Hispaniola into two colonies: Santo Domingo the Spanish colony, which is now the Dominican Republic and the French colony of Saint Dominique which is now present day Haiti. African slave labor became an important component to the economic development of both of the respective colonies, but there was a large difference in the sheer number of slaves and the slave to colonizer ratio on the French side of the island in comparison to Spanish colony: "As of 1800, there were about 500,000 slaves and 75,000 French settlers in Haiti, compared to 40,000 slaves and 10,000 Spanish settlers in the DR" (Martin, Midgley, Teitelbaum 2002:572). The difference in the African population between the two colonies combined with the economic structure provides insight into the racial make-up of these countries today.

Saint Dominique (Haiti) was one of the most important colonies for the French during the eighteenth century, profiting mainly from the lucrative plantation style sugar industry which demanded thousands of African slaves (Wucker 1999, Howard 2001).The plantation economy of Saint Dominique required a rigid slave/ master relationship; slaves in the French colony did not racially or socially mix with their colonizer. Due to the strict separation between slaves and colonizers, slaves maintained their racial and cultural "blackness" and were differentiated socially and culturally (Candelario 2007). The African slave population composed the majority of the population, with six times as many slaves on Saint Dominique as there were colonizers; the large number of African slaves coupled with the lack of inter-racial mixing is responsible for the largely black population of Haiti (Moya-Pons 1995). 
The colonial reality in the Spanish Santo Domingo differed greatly from the French/Haitian side. In the $18^{\text {th }}$ century the colony of Santo Domingo on the Spanish side of Hispaniola was suffering from economic decline, due to massive depopulations caused by the decline of the sugar industry, white emigration, and the impoverishment of Spanish and Creoles (Candelario 2007).With the decline of the sugar industry motivated the Spanish colony to turn to cattle production, where slave labor became decreasingly important and the relationship between slave and colonizer began to change.

The declining Spanish population required the inclusion of blacks and mulattos in the armed forces and in religious infrastructure (Candelario 2007). Many academics of this time described the relationship between slaves and the colonizers as negligible, as rigid racial codes broke down in Santo Domingo (Moya-Pons 1995; Wucker 1999; Howard 2001, Torres-Saillant 2000). The social distance between blacks and whites shrank and there was a pervasiveness of mixed heritage. This provided slaves and former slaves the opportunity for upward mobility and social equality, impacting the racial make-up and consciousness of blacks and mulattos in the Spanish colony. In the Spanish colony "Black" became associated with slavery, whereas the mulattos were able to identify themselves in accordance to their social or political standing (Torres-Saillant 2000: 1095).

In the Spanish colony of Santo Domingo, the economic circumstances of the $18^{\text {th }}$ century influenced the way in which blackness began to lose its connection to biological features and traits, and become socially constructed. Social status superseded skin color and contained strong anti-African and pro-Hispanic sentiment for blacks and mulattos in Santo Domingo (Torres-Saillant 2000: 1096). Those on the Dominican side, regardless of 
their color called themselves "whites of the earth" because they were born Creole and not African like their colonized neighbors (Sagás 2000:29). The socioeconomic realities of blacks and mulattos in the Spanish colony influenced their perspective of themselves; the Santo Domingo side saw themselves as Spanish, white, catholic, with a Hispanic culture. Whereas the French slaves were black, practiced voodoo, and from the perspective of the Dominican elites, had an African culture thinly veiled with French.

The rhetoric and dichotomy between Haitians and Dominicans is very similar today as it was during the colonial period. Examining the colonial history allows us to understand the long history and development of antihaitianismo and the Dominican conceptualization of race. The colonial history not only aids us in understanding the phenotypical differences between Haitians and Dominicans, as Haitians are typically blacker than Dominicans, but also the socio-ethnic formation of Dominican identity. In the colonial period Dominicans began to distance themselves from blackness and African heritage, distinguishing themselves from Haitians, and considering themselves to be racial and culturally superior.

\section{Haitian Revolution}

In 1789 the beginnings of slave rebellions began to erupt in the French side of the Hispaniola Island, at this time the enslaved population composed nearly $90 \%$ of the total population in the French colony (Howard 2001). This rebellion lasted until 1804 when under the leadership of rebellion leader Toussaint L'Ouverture the colony became the first free Black Republic (Wucker 1999). All residing on the Haitian side of the island were to be considered noir or black under the new constitution; "the constitution of the new country expressed its identity: it was to be a black republic named after the 
indigenous word for the island" (Wooding and Moseley-Williams 2004). This is

considered the first time the idea of black has been used as an ideological term (Howard 2001:27).

At this same time the other side of the island, the colony of Santo Domingo was beginning to identify black as a pejorative term associated with slavery and Africa, as the newly formed Haiti self-proclaimed itself as a black nation and proudly embraced their African culture and heritage.

The Haitian revolution is the first and only slave rebellion to result in the creation of a state. The rebellion is considered a great accomplishment as the revolt had an impact on both the enslaved and colonized populations: "word of the Haitian Revolution did in fact reach and inspire Africans throughout the Diaspora to revolt and pursue emancipation, including those in the neighboring islands of the Caribbean and in the United States" (Candelario 2001:43).

The Haitian revolution sent shocks through the slave owning world and presented a challenge to white supremacy (Candelario 2001). Due to the international reaction of the revolution, Haitian leaders felt a sense of urgency to protect their new freedom. Haiti believed that in order to remain a free nation it would have to occupy Santo Domingo to prevent other enslaving colonies opportunity to invade the island (Wooding and MoseleyWilliams 2004).

\section{Haitian Occupation}

The Dominican Republic is the only Latin American country that did not gain its independence from a colonial power, but rather from its neighbor Haiti after a 44 year occupation. Although this historical event occurred over 160 years ago, it still informs a 
large part of the antihaitianismo ideology, and is an important part of Dominican culture and identity. In David Howard's (2007) study conducted in 2006 on race and discrimination in the Dominican Republic his interviewee's expressed the principal motivation for resentment towards Haitians to be in reference to the 1822-1844 Haitian occupation.

In the beginning of the $19^{\text {th }}$ century the colony of Santo Domingo was economically and militarily weak, while the newly independent nation of Haiti developed into a strong economic and military power. While the Dominican Republic debated on whether to join Simon Bolivar's Gran Colombia, the Haitian president Jean-Pierre Boyer began to gain mulatto and black support for the occupation of the Dominican Republic through promises to eradicate slavery (Moy-Pons 1995).

On November $9^{\text {th }}, 1821$ Dominican Republic declared its independence from Spain, with the intention of petitioning Bolivar's new union, yet Boyer had already garnered a mulatto majority in support of a Haitian occupation (Moya-Pons 1995). On February $8^{\text {th }} 1822$, the Dominican President, Jose Nuñez de Caceres handed the key to Santo Domingo to the Haitian President Boyer. This began the 22 year Haitian occupation of the Dominican Republic.

During the occupation, the Haitian government quickly became unpopular quickly with its new Dominican citizenry; in order for the Haitian government to repay its indemnity of 150 million francs to the French, Boyer began to make quick changes to Dominican society. The Haitian government began to redistribute the division of land, dispersed the wealth of the clergy and church, and called into action a series of codes requiring all Dominicans to perform labor as part of the indemnity repayment plan 
(Moya-Pons 1995).The oppressive rules of the Haitian occupiers inspired the creation the revolutionary group the Trinitarios, who eventually lead the Dominican Republic to reclaim its independence from Haitian rule on February $27^{\text {th }} 1844$.

The Haitian occupation has become a historical injury that has remained relevant in the Dominican present; according to Andres Corten and Isis Duran (1995), "In Santo Domingo the wounds inflicted by the Haitian occupation led by Jean-Pierre Boyer (18221844) have systematically been reopened" (p. 95). These wounds have been used by the elites and Dominican politicians, such as the Dominican Dictator Trujillo and twelve time president Joaquin Balaguer to forge a national identity in antithesis to Haiti.

The elites and political figures have often posed the idea that Haitians will always have the desire to reoccupy the Dominican Republic, and their migration is a form of a "passive invasion" of the country (Howard 2007). According to Howard, "the expressed importance of maintaining an intact physical boundary against 'remembered' past abuse underpinned the reproduction of normative radicalized prejudice and aggression against people of Haitian descent" (Howard 2007:728). The occupation and the continued armed conflicts between the Dominican Republic and Haiti have characterized a lasting Dominican suspicion of Haitian intentions therefore characterizing the relationship between the two countries as antagonistic, at least from the Dominican perspective (Wooding and Moseley-Williams 2004).

The imagined threat of a possible Haitian re-occupation informs the racial distinction between the two countries, as Haitians desire to "Africanize" the Dominican Republic, or culturally pollute the Dominican Hispanic and Catholic culture with Voodoo and backwardness. The liberation of Haitian rule is still celebrated today as one of the 
Dominican Republic's greatest feats, and the possibility of a Haitian pacific invasion is an integral part of the antihaitianismo ideology. Dominican collective consciousness views Haitians as their greatest enemy, and Africanization of the Dominican Republic one of the biggest cultural threats.

\section{Outside Influences on Antihaitianismo}

After the Dominican Republic won their independence from their Haitian neighbors, the country's history of colonization, occupation, and poverty informed the country's economic desire to become part of a larger economic order that was controlled by Western powers. The U.S. under president Ulysses S. Grant demonstrated interest in annexing the Dominican Republic with the possibility of statehood (Candelario 2001). The prospect of American annexation motivated the Dominican population, especially the white elite to become concerned with the issue of race and their relation to their Haitian neighbors (Torres-Saillant 2000).

The Haitian Revolution, posed an ideological threat to slaveholding countries and white supremacy around the world, as the event inspired the African Diaspora to pursue emancipation throughout the Americas (Candelario 2001:43). Dominicans in the $18^{\text {th }}$ and $19^{\text {th }}$ century viewed themselves as not only different but superior to their Haitian neighbors as travel writers commonly portrayed Haiti as overly black, overpopulated, and underdeveloped. Many accounts also noted Haitian sexual rapacity and the invasion of Haitians as the reason for the retardation of the development of the Dominican Republic (Candelario 2001:43).

The elites of the Dominican Republic felt the need to distance themselves as much as possible from their neighbor, therefore becoming: "a useful and willing "non- 
black" antithesis to Haiti and its black-liberation agenda" (Candelario 2001: 43). The creation of Dominican national identity post- Haitian occupation heavily considered how other powerful nations viewed them, according to Silvio Torres-Sailliant (2000) "the texture of negrophobic and anti-Haitian nationalist discourse sponsored by official spokespersons in the Dominican state may have drawn significantly from North American sources dating back to the first years of the republic" (p. 1088). The Dominican Republic placed itself in contrast to the Haitian black nation in order to attract attention from countries such as the United States, and therefore fortifying Dominican identity creation in contrast to Haitians.

\section{Trujillo and Dominicanidad}

An examination of the colonial period through the Haitian occupation of the Dominican Republic allows for an understanding of the trans-historical development of the different ideological components of antihaitianismo; yet no individual or event has been credited more with the propagation of antihaitianismo then the dictator Rafael Leonidas Trujillo. Trujillo ruled the Dominican Republic from 1930 until his assassination in 1961. In addition for concretizing antihaitianismo as a national ideology, his 30 years reign is credited with being one of the bloodiest eras ever in the Americas (Candelario 2001).

As Trujillo came in to power in 1930 he perceived the Dominican Republic as backward and in need of modernization; in order to remedy these problems he began a process of national reconstruction based on the political unification of the territory (Moya-Pons 1995:360). Cultural and ethnic hegemony was important to the Trujillo regime, and he viewed Haitian presence as detrimental to the country's modernization. 
Trujillo's team of intellects launched a propaganda campaign that worked toward the "Dominicanization" of the nation; the goal was that every single Dominican child would know that Haitians were a threat to everything true and right in Santo Domingo (Wucker 1999:54).

The Haitian Massacre of 1937, also known as El Corte, is sometimes recognized as the introductory efforts of Trujillo's nationalist agenda and the incorporation of antiHaitian sentiment into Dominican nationalism. Before the massacre anti-Haitian propaganda was largely absent from Dominican society, and the frontier was considered a place of intercultural exchange, where there was little governmental control over the flow of people or goods by either government (Wooding and Moseley-Williams 2004; Martinez 2009; Turits 2002).

Cultural homogeneity became the means through which Trujillo would re-build and fortify the republic; "the Trujilloist ideology re-stressed the Dominican Republic as a Hispanic, Catholic and white nation. African influences were considered non-Dominican and thus subversive of the state" (Howard 2001:31). Within Trujillo's administration were intellectuals who held very racist and culturist notions, two of the most influential were Manual Arturo Peña Batlle and Joaquín Balaguer. These intellectuals helped scope out what Samuel Martinez (2009) calls Trujillisimo, where Haitians were understood to pose a political, cultural, and territorial threat to the Dominican nation.

Trujillosim took the traditional elite attitudes and prejudices against Haitians, developed in the colonial period, which emphasized Haiti's "Africanisms", creolized French, their superstitions and fetishism of Voodoo (Turits 2002). Trujillo promoted Dominicanidad/Antihaitianismo and a complete erasure of African heritage from 
Dominican culture through schools, the press, radio, public monuments, and direct political activities (Martinez 1999). Trujillo was able to use the country's best intellectuals, cultural institutions, the media, and the Catholic Church to create a state machine that perpetuated the antihaitianismo myth as part of Dominican national identity.

It is important to emphasize that the Dominican public was subject to 31 years of strategic antihaitianismo and nation-building propaganda during Trujillo's rule. Trujillo was succeeded by the twelve year "Presidency" of Joaquin Balaguer, one of the most influential academics during the Trujillo dictatorship and a staunch proponent of antihaitianismo ideology. According to many academics of Dominican culture Trujillo and Balaguer's legacy of antihaitianismo is still alive today in the form of neoantihaitianismo (Sagás 2000).

\section{Neo-Antihaitianismo}

The end of the Trujillo era did not signify the end of institutionalized antihaitianismo doctrine or ideology; Joaquín Balager, Trujillo's right hand man, and the intellectual architect behind the new Dominicanidad promptly took Trujillo's place. Balaguer would hold the office of President for what is called in Dominican politics the 12 years; he ruled from 1960 to 1962, from 1966 to 1978, and again from 1986 to 1996. Balaguer's views differed from Trujillo's in the sense that Balaguer's views and writings were considered extremely racists. The incorporation of strong racist overtones with antihaitianismo became known and dispersed through two of his most famous books $L a$ Realidad Dominicana written in 1947 and La Isla al Reves, written in 1983 (Wooding and Moseley-Williams 2004: 21). 
Throughout his presidency Balaguer maintained an anti-Haitian policy, perpetuating the idea that Haitians wanted to unite the island once again, he is quoted stating: "The idea in itself is infantile and even ridiculous. Water and oil can coexist for many years, but cannot be mixed together without losing their organic composition or giving up their identities" (Wucker 1999:75). Bridget Wooding and Richard MoseleyWilliams (2004) describe Balaguer's writings and publications as a "vulgar form of social Darwinism" (p. 21).

The tenets of both Balaguer's and Trujillo's state ideology is that the Dominican Republic is a white Hispanic nation and the country is damaged by the presence and mixture with Haitians. The presence of Haitians is detrimental to the Dominican Republic as it denigrates the moral and spiritual strength of Dominicans. Haitians are responsible for poverty, ignorance, disease, and crime (Wooding and Moseley-Williams 2004:21). Haitians are presented as aggressors and the reasons for most of the DR's problems (Sagás 2000).

Trujillo and Balaguer were very instrumental in crafting the ideology of antihaitianismo and institutionalizing the myth in Dominican culture. Over the 42 years that these two important Dominican figures held power, the state sponsored ideology of antihaitianismo was pervasively weaved into all institutional areas of social life; being taught in school, in the media, and through all educational sources.

The tenets of Antihaitianismo that were developed in this time are still functional today as racism and negative attitudes toward Haitians are still very common place (Sagás 2000).The notions of identity, culture, and nation are very intertwined, and Dominicans are conditioned from a very young age to believe that Haitian race and 
culture are contrary to everything Dominican. Balaguer even went as far to state that "The influence of Haiti has also had a disintegrative effect on the Dominican soul" (Sagás 2000: 71).

The historical Dominican-Haitian relationship from the Dominican perspective demonstrates that antihaitianismo as an ideology has its beginnings in the colonial period, and has continued to develop since. Antihaitianismo and Dominicanidad have been political tools of the ruling class, used to inflame anti-Haitian sentiments and promote social and racial rejection of immigrants. The modern manifestation of antihaitianismo focuses on Haitian immigration, adhering to Balaguer's claim that Haitians will take over the DR through a pacific invasion.

The logic of this argument is that Haiti lacks the military and economic strength to take over the DR through force, and has therefore resorted to a demographic invasion through immigration (Sagás, 2001). Therefore Haitian presence and migration, despite the important contributions to the Dominican economy, should be regarded as having malicious and deceptive intents. Dominican national identity is formed in a way that it portrays the Dominican nation under the imminent threat of the Africanization of Haitians (Rosario and Ulloa 2006: 75). The result of the ideology has meant the social, cultural, and legal segregation of Haitians in Dominican society.

\section{$\underline{\text { Theoretical Literature }}$}

\section{Nation-State Sovereignty}

The Dominican immigration reform as a whole targets Haitians and Dominicans of Haitian descent, yet within a global context the DR fits within a trend of increased preoccupation and criminalization of undocumented immigration (Cornelisse 2010; Peutz 
and DeGenova 2010). According to DeGenova at the beginning of the $20^{\text {th }}$ century it was considered unconscionable to inflict the hardship of expulsion on unauthorized migrants, compared to the latter part of the century where the increased global fluidity of people has directed the focus of immigration law to regard more individuals as unfit for citizenship or consider them "illegal aliens"; making them subject to arrest, deportation, and detention (Peutz and DeGenova 2010: 13).

The question of how the Dominican Republic and other countries can relegate hundreds of thousands individuals to statelessness and deportability is premised on the logic that the Dominican Republic is sovereign nation within the global nation-state system, and may therefore use deportation as a form of state-craft.

The world is divided into territorially defined sovereign nation-states, or the Westphalia system, in which the term territoriality denotes the "founding of political authority on demarcated territory" and state sovereignty defined as the "perpetual and absolute power of a republic" (Cornelisse 2010: 120). Territorial nation-state sovereignty is the basis for the territorial division of the world into defined populations, which form the basis for the determination of rightful members of a territory (citizens), and nonmembers (aliens) (Peutz and DeGenova 2010).

Within the nation-state system states are obligated to protect and control their borders; "illegal" or unauthorized immigration may pose a threat to the State because they undermine the control of national boundaries and the state system. Immigration enforcement, such as deportation or detention, are state sponsored responses to this threat and an expression of state sovereignty that allows states to assert their power and control through ordering the global movement of people (Cornelisse 2010). 
In the context of the existing nation-state system, immigration enforcement such as deportation and detention appear to be natural and almost necessary responses to unauthorized entry into a territory. The perceived naturalness of the connection between people, territory, authority, and the distinction between insiders and outsiders, has contributed to the portrayal of immigration as a phenomenon that upsets the existing order (Cornelisse 2010). Many scholars have questioned the naturalization of the modernstate system and the need to control and punish the movement of people.

Within the modern state-system excessive movement or nomadic tendencies are problematic, the creation of immigration laws and deportation are meant to control the movement of people under the premise that all individuals belong to a territory under a sovereign state. For Cornelisse (2010), the territoriality of the global system "impedes the realization of human rights' universal aspirations, as the question of access to rights is still largely determined by a global regime of governance that decrees where one belongs"(P. 127). Cornelisse (2010) argues that the nation-state system grants territories unrestrained power through their ability to use their sovereignty to validate politically particular means of determining inside and outsiders to make deportable and rightless undesirable populations.

The creation of universal human rights regimes and international law were intended to mitigate the power of the state. According to Cornelisse (2010), neither human rights regimes nor international law have developed the language to approach state sovereignty claims; as the enforcement of human rights is still largely reliant on cooperation from the state (Cornelisse 2010). The modern state system based on territoriality appears to be sacred and untouched, which allows for the international and 
national justification of deportation of those that present a "threat" to national sovereignty (Cornelisse 2010).

International law has worked to uphold the sanctity of national borders; citizenship grants rights to those who "belong" within a nation-state; and the insurance of human rights are reliant on the state. Therefore those who are "illegally" present within the state fall into a space where they are not protected by national or international law.

There is a gap between national and international law, in which those who do not belong to the state are without rights, and without the protection of so-called inalienable human rights. It is within this gap that the stateless, the "illegal", or the unwanted fall. It is within this gap that individuals like Haitians and Dominicans of Haitian descent lose their juridical personhood and civil identity. For Dominicans of Haitian descent who has considered themselves Dominican all of their lives, the stripping of their citizenship also results in a loss of cultural and social sense of their identity as well.

Within the system of territoriality, the absence of citizenship reduces individuals to the most basic human level, which requires them to economically sustain themselves within a territory where they have been excluded by the state, yet the state has power over them (DeGenova 2010:37). It is the vulnerability and "illegality" that qualifies undocumented labor as a highly exploitable workforce (DeGenova 2010).

\section{Conceptualizing Citizenship}

Within the last ten years, the concept citizenship has become increasingly central to the lives of Haitians and Haitians of Dominican descent living in the Dominican Republic. Citizenship implies membership in the society where one lives and works, it is the concept that connects a community to a geographical location and encompasses the 
dimensions of identity and belonging, rights and duties, and legal status and protections (Bolemaradd, Korteweg, and Yurdakul 2008).

Citizenship is the guarantor of rights within the nation-state. The negation and retroactive stripping of citizenship has been the mode through which the Dominican State has ensured that Haitians are unable to become part of Dominican society. The sociocultural situation for Haitians is imbued with antihaitianismo and discrimination, this stigma is institutionalized when citizenship is revoked or negated.

In conceptualizing citizenship, many sociologist have taken T.H. Marshall's model of social citizenship from his seminal essay "Citizenship and Social Class" as a starting point. Marshall defined citizenship as "a claim to be accepted as full members of the society", in which citizenship is a reciprocal exchange between the state and the individuals who live and participate within a specified geographical space (Isin and Turner 2007:14). Within this framework individuals contribute to the state in the form of work or public duty such as military service, and the state reciprocates with social rights which guarantee workers "a modicum of civilized life by protecting them from the unpredictable vagaries of accident, sickness, and unemployment" (Isin and Turner 2007:7).

Marshall's model of citizenship has a universal character, in which all individuals enjoy a full and uniform access to rights basis of citizenship and membership in society regardless of their social class (Isin and Turner 2007). In the last two decades Marshall's model of citizenship has come under criticism for its universal and homogenizing characteristics which belies the social and economic inequalities within a society (Baines and Sharma 2002). 
Deviating from the universal character of Marshall's model of citizenship, Baines and Sharma (2002) argue that the concept of citizenship involves notions of gender, nationhood, colonialism, neocolonialism, and a binary of Self-citizen/Other-non-citizen. Their assertion is that citizenship is exclusive and strategically relational; taking the US. as an example, their work explores how feminist and anti-racist writers have pointed out that equal civil, social, and political rights for marginalized groups such as women and African Americans in the US were gained through a lengthy gendered and racial struggle that continues today (Baines and Sharma 2002). Political and social struggles for recognition and economic redistribution within frameworks of citizenship have required more complex social- scientific interpretations of citizenship that recognize difference and pluralism (Isin and Turner 2002; Chauvin and Mascareñas 2012).

Despite expanded notions of citizenship which recognize cultural plurality, the Marshallian concept of citizenship has been further challenged as it cannot encapsulate all of the dynamics of social life, especially as large numbers of individuals of diverse ethnic and racial backgrounds cross national boundaries seeking new opportunities through immigration (Bolemaradd, Korteweg, and Yurdakul 2008:154). Linda Bosniak (2007) cleverly asserts that the concept of citizenship can present a paradox in the way that it is "hard on the outside and soft on the inside" (P. 2451). On the inside, nationstates citizenship may present the Marshallian characteristic of universalism; yet when looking outside toward the border or outside citizenship has a more exclusionary characteristic, citizenship works to unapologetically keep non-citizens out (Bosniak 2007: 2451). 
Immigration possibly renders Marshallian citizenship no longer plausible, as immigration reveals citizenship as not only as a package of rights, but also a legal status that demarcates the boundaries between individuals within a nation-state, demonstrating the exclusionary characteristic of citizenship. The 'hard shell' of citizenship is confronted by immigration, as migrants challenge the concept of citizenship through challenging the notions of national identity and state control. Citizenship therefore creates a group of those who are outsiders or non-citizens, whose rights and obligations to the state are different based on this category. For Baines and Sharma (2002) the concept of citizen and non- citizen have always existed together throughout the history of citizen-making; the very creation of the citizen activates the category of non-citizen.

Baines and Sharma (2002) argue that within the context of fluid global markets the legal and ideological production of citizenship functions to develop and maintain a pool of "highly exploitable and socially excluded workers" (p. 76). As individuals cross borders to find better economic opportunities, they represent an economic commodity when their rights can be restricted through their noncitizen status.

Tuner and Isin (2002) follow Baines and Sharma in asserting that while citizenship became a platform for exclusion and 'national manhood' in the $19^{\text {th }}$ century, "in the 20th century it has often been intimately connected with the construction and maintenance of a global labor market of guests and aliens" (P. 6). Sharma (2012) argues that the institution of citizenship is more than a political category, but is a marker of one's position within nationalized labor markets.

Harald Bauder (2008) also shares the perspective of the intimate connection between citizenship and the creation of a non-citizen workforce. In his study on migrant 
workers in Canada, Bauder develops a perspective of citizenship which expands Pierre Bourdieu's ideas of capital and the process of inclusion and exclusion under the logic of distinction and reproduction. Bauder (p.315) conceptualizes citizenship a strategically produced form of capital that is manifested both in the formal and informal aspects of citizenship and works as a mechanism of distinction between migrant and non-migrant workers. Bauder (p.321) argues that as industrial economies have become dependent on migrant labor, citizenship becomes part of an economic agenda to extend or withdraw economic rights to "cheapen labor power" of migrant workers.

Bauder's conceptualization of citizenship builds on Bourdieu's logic of distinction and reproduction where the dynamics of the social world involves an analysis of the functioning and accumulation of different forms of capital. In Bauder's analysis citizenship is strategically managed not only to guarantee a continual supply of vulnerable workers, but to also prohibit non-citizens from accumulating or activating economic or social capital, ensuring the reproduction of economic privilege and social status of citizens and therefore subordinating non-citizen workers.

Marshall's concept of citizenship places our focus on those that are included within the category of citizenship, but as the differentiated groups who challenged citizenship models have demonstrated, it may obscure those who are included through their exclusion from citizenship. The work of Baines and Sharma and Bauder draw our attention from the sole focus on citizenship but to the relationship of both the citizen and the non-citizen; while citizenship may contain an exclusionary aspect, these authors draw attention to the non-citizen category can become a mechanism of inclusion into the labor market as a subordinated workforce. Many students of Dominican- Haitian relations have 
made this very argument: the Dominican Republic's failure to introduce effective migration and citfizenship legislation works strategically to regulate and control cheap Haitian labor (Howard 2001; Sagas 2000; Wooding and Moseley-Williams 2004).

The lack of citizenship and the historic stigma make it difficult or Haitians to blend into the fabric of Dominican society- effectively creating a dual class of citizens; those who can make claims against the state and Haitians who cannot. Despite almost a decade of Haitian migration to the Dominican Republic, the Dominican state has until recent years began to address question of regularization and clear immigration laws which have worked to mainly disenfranchise and other Haitians and their descendants born in the Dominican Republic, pushing Haitians and Haitians and their desendants into non-citizen status.

The Dominican Republic is beginning to develop what Baines and Sharma (2002) call "hierarchies of belonging," which are created and maintained through the acceptance that states can legitimately discriminate against foreigners, and that only citizens can make claims against the state (Baines and Sharma 2002: 84).

\section{Fetishization of Illegality}

The unauthorized crossing of a border characterizes an immigrant's relationship to the receiving nation-state, through their border crossing they have acquired a “spatialized socio-political condition" of "illegal” or "alien” (DeGenova 2004: 161). The concepts of "illegal" immigrants or "illegal aliens" are widely used and have become the focus of conversations and literature discussing immigrant status in the media, politics, and in scholarship. Despite the usage of these concepts many scholars (DeGenova 2002; Karakayali and Rigo 2010; Portes 1978) question the impact and analytical significance 
of the unquestioning use of these terms as analytical concepts, and whether they work to contribute to an "uncritical reproduction of hegemonic common sense" (DeGenova 2002:432). Karakayali and Rigo (2010) argue that "illegality" is not an analytic sociological category, yet its use as a category of analysis or as an object of policy is rarely questioned.

According to DeGenova (2013), migrant 'illegality' tends to be considered immutable and unquestionable, as if it were an abstract "matter of fact" concept that existed without the law; this is what DeGenova calls the fetishization of migrant illegality (p. 1182). In order to avoid the fetishization of illegality in his work DeGenova deploys quotation marks around the words "legal" and "illegal" to modify migration or migrants in order to denaturalize these categories and not contribute to their reification. This paper will do the same, in order to contribute the analytical perspective of these concepts.

The fetishization of migrant "illegality" detaches the social and political relationship between migrants and the state, and places the burden of illegality on the migrant, as though migrant "illegality" was a private affair or a sociopolitical disability (DeGenova 2013). The fetishization of illegality seems to imply that becoming a citizen is a matter of free choice, in which "illegal" immigrants have neglected to go through the appropriate channels to naturalize their status.

DeGenova works to denaturalizes migrant "illegality" by highlighting the fact that undocumented or "illegal" populations are not random or self-creating, and "illegality" is not a characteristic of a specific person or group; migrant illegality is created by immigration law which is mediated through social and economic mechanisms (Donato and Armenta 2001:537). 
Despite the influence of the law in determining migrant status, according to DeGenova (2004): "across an extensive body of multidisciplinary scholarship, one encounters a remarkable visibility of "illegal immigrants" swirling enigmatically around the stunning invisibility of the law" (p.167). Denaturalizing the category of illegality requires a perspective that moves past "illegality" as naturalized fact of transgression or clandestine border crossing to an examination of other dimensions of migrant illegality, such as the social and economic influences on the production of "illegality" through immigration law. Examining migrant illegality through this perspective opens the possibility to develop that perspective of immigration law and migrant "illegality" as strategic tools used by nation-states to develop a subordinate workforce.

Migrant "illegality" creates a position of vulnerability, as the unauthorized entry of migrants become subject to the state's enforcement apparatus through the criminalization of their act (Portes 1978:474). The fact that migrants have violated the law makes them vulnerable, as their "illegality" can be appropriated by employers. According to Portes (1978), immigrant workers are not exploited because of inherent qualities of docility or compliance, but through the position of weakness that is created through their legal and political status.

"Illegality" is useful resource for nation-states that purports deviance and subversion, but is a conduit through which states are able to channel and absorb a flexible workforce motivated by the global movement of people (Sharma 2012:4).This perspective of taking illegality as a subject of study rather than naturalizing it allows us to attempt to understand the motives of the state in creating illegality. 
The Dominican Republic presents an interesting opportunity to conduct a study on the production of illegality, as the legal and social creation of a large "illegal" and deportable population has developed within the last 10 years. The stigma from Haitian migrants as violators of the law and territory, combined with the deeply embedded historical stigma of Haitians as invaders and racially contaminating, intensifies the social situation and vulnerability for Haitians.

The Dominican state has worked steadily since 2004 to construct illegality through different pieces of legislation; yet before the passage of the legislation many Haitians of Dominican descent lived as Dominican citizens their entire lives. According to Karakayli and Rigo (2010), most scholarly or public debates concerning migration are framed by misconceptions of clandestinity (p.136); the Dominican case provides a case for the examination of the socio-legal production of illegality as this is not a case of clandestinity but the case of the creative use of the state's sovereign power.

\section{Border Spectacle}

According to DeGenova, the border is where migrant illegality is activated through the performative act of border enforcement; this is what he terms the Border Spectacle. Migrant "illegality" is a juridical status that demarcates individuals as noncitizens, but also includes a spatialized relationship between an individual and the nationstate. Immigration law criminalizes undocumented immigrants for existing within the boundaries of the nation-state, therefore making them subject to arrest, deportation, and detention (Peutz and DeGenova 2010: 13).The search and apprehension of "illegal" immigrants, or even the seemingly simple inspection of documents transforms the border into a place of detection, interception, or deportation (DeGenova 2013:1183). 
The border provides the theater for this performative act of exclusion, the spectacle where migrant illegality is dramatically activated and the "illegal alien" is reified and inscribed on immigrants and non-citizens (DeGenova 2002:436). The Border Spectacle creates the fetishism of illegality by removing "illegality" from its production, and places the focus on the "scene of the crime" through the enforcement of a violation, this lends "illegality" an objectivity that obscures the relationship between the immigrant and the state (DeGenova 2013: 1189).

To be clear, borders do not have to be the literal geographical line dividing a territorial space, an entire nation-state can become a space of regulation or a "border", as the exclusionary character of citizenship becomes internalized (Bosniak 2007: 2451). "Borders" take on a more conceptual meaning as they become internalized and invoke the discriminatory treatment of non-citizens, as the "border" trumps an individual's rights (Bosniak 2007).

Therefore physical borders are meant to keep noncitizens out, but also become internalized to exclude and restrict the rights of those already on the inside. Through the broader concept of the "border" the Border Spectacle becomes intensified as "illegality" becomes more ubiquitous (DeGenova 2013:1183). Migrant "illegality” combined with the Border Spectacle work to discipline and control immigrant populations through the constant threat of apprehension and deportation.

According to DeGenova the Border Spectacle and the fetishization of the supposed transgression of "illegal" immigration hides the publically unacknowledged secret of the sustained recruitment of undocumented labor (DeGenova 2013: 1185). Borders are spaces of larger sociopolitical processes of inclusion through legal exclusion 
and labor importation which is based on the protracted deportability of immigrants; this is what DeGenova calls or the "obscene of inclusion" (DeGenova 2013:1184).

The performance of the Border Spectacle as policing and exclusion, while at the same time borders are also sites of mass recruitment and inclusion of immigrants (DeGenova 2013: 1189). For DeGenova the Border Spectacle is an ideological edifice, that supports immigration law, which works to not only normalize illegality and exclusion, but also the inclusion of migrant labor as well (DeGenova 2013: 1189).

\section{Deportability}

The implementation of the Border Spectacle guarantees that immigrants who do manage to successfully cross borders will live the precarious conditions of being susceptible to detention or deportation; this is the condition of deportability. The condition of deportability carries with it the protracted condition of needing to live, work, travel clandestinely from authorities; this subjugation to surveillance is subordinating and disciplinary (DeGenova 2013). In the example of Mexican migrant workers in the US, deportability is decisive in the production of "illegality", while some migrants may be deported, most of them remain un-deported, but will bear the status of and deportable on the occasion of being apprehended (DeGenova 2004).

Therefore some migrants must be deported so that the others may stay, under the subordinated always monitored condition of deportable. As most migrants stay and will not actually be deported, deportation appears to be a threat, a way to put migrants in their place. The goal of immigration policy does not necessarily have to focus on restricting mobility, but rather to restrict the freedom and rights of individuals within the labor 
market (Sharma 2012:32). Therefore deportability is a way to keep "illegal" migrants in their place.

Before the immigration reform the Dominican state often used deportation as a mechanism to discipline Haitian laborers through random raids and checkpoints. This is especially true in periods of heightened political periods or during events, such as the cholera epidemic or a trade embargo imposed on the Dominican Republic from Haiti. Checkpoints line the southern coast and along the border, where Haitians and darkskinned Dominicans may be pulled off buses to pay a bribe to the police who guard the checkpoints.

The new Constitutional Court ruling will now add approximately a quarter of a million Dominicans of Haitian descent to the already existing half a million population of undocumented Haitian immigrants in the Dominican Republic. It seems implausible that the Dominican Republic expects to deport this entire population. The act of changing their status and making these individuals non-citizens and potentially illegal, makes them subject to the Border Spectacle. The state can choose to deport these individuals, and will most likely deport a portion of the population, but it is probably that the majority will stay, under surveillance and the subordinated category of deportable "illegal" immigrant. 


\section{CHAPTER III HAITIAN IMMIGRATION TO THE DOMINICAN REPUBLIC}

\section{Haitian Immigration History}

Once called the Pearl of the Antilles, Haiti was once the richest colonies in the West Indies during the 18th century; today Haiti is the poorest country in the Western Hemisphere, with $80 \%$ of its population living below the poverty line (World Bank 2012). While Haiti has suffered many political and environmental disasters, the Dominican Republic has experienced prolonged economic expansion. The economic developments between the two countries have developed a migratory push away from Haiti and a pull toward the Dominican Republic (Wooding and Moseley-Williams 2004).

Haitians immigration has bolstered the most important economic sectors within the Dominican economy, beginning with the development of the sugar cane industry. Since its inception, Haitian migration to the Dominican Republic has been closely related to the Dominican need for a large labor force and the unequal capitalist development on either side of the island (Rosario and Ulloa 2006). This was true in the era of sugarcane and continues to be the case today.

What follows is an analysis of Haitian immigration into the Dominican Republic. This analysis will provide the social and historical context for understanding and interpreting the immigration legislation. 


\section{Bracero Program}

The story of large scale Haitian immigration to the Dominican Republic begins with the development of the Dominican sugar cane industry. The decline of Europe's sugar-beet industry at the end of the $19^{\text {th }}$ century positioned the Dominican Republic to take advantage of a rising demand of sugar in the world and especially in the U.S. (Wooding and Moseley-Williams 2004). During the U.S occupation of the Dominican Republic from 1916-1924, American multi-nationals began to develop vast sugar plantations, which later came under ownership of the Dominican state (Wucker 1999). The sugar industry became one of the most important agricultural industries in the Dominican Republic. The lynchpin in the success of this labor intensive industry was the availability of cheap laborers from Haiti, who could be controlled to create a compliant temporary workforce.

The Dominican state initially employed Dominicans, and then West-Indian immigrants, but as the price of sugar began to fall the industry required a larger and cheaper workforce (Martinez 1999). In Haitians, the state found a cheap, docile, and desperate workforce capable of supplying the growing sugar industry's labor needs, at half the wage their West- Indian counterparts were earning(Martinez 1999).The Dominican government took an active role in both the recruiting and the policing of thousands of Haitian cane workers that entered the Dominican Republic each year, through the creation of state sponsored bilateral labor contracts between the dictatorships of Rafael Trujillo in the Dominican Republic and the Haitian Dictator Jean-Claude Duvalier (Baby Doc) in Haiti (Martinez 1999, Wooding and Moseley-Williams 2004). 
The bilateral labor agreements, were established in 1952 and lasted until the fall of Jean-Claude Duvalier in 1986; these agreements were also known as the Bracero Program and allowed the Dominican state to supply the growing sugar industry with cheap abundant labor the industry demanded. The contracts required the Dominican government to make payments to the Haitian government in US dollars for the delivery of thousands of Haitian seasonal workers (Wooding and Moseley-Williams 2004). The contracts stipulated that the Dominican government was to ensure: the entry and repatriation of the workers, minimal living conditions, and medical insurance (CEFASA/CEFINOSA 2012:84).

Despite the stipulations regarding the working and living conditions of Haitian workers, their reality was often compared to slave-like conditions, or what anthropologist Samuel Martinez (1999) terms un-free labor: migrant labor system controlled by semicoerced exploitation rather than by market-forces (Martinez 1999). Haitian migrant laborers lived and worked in labor barrack settlements called bateys. These settlements are economically and spatially isolated from larger Dominican society, and were (and still are today) the most impoverished pockets of the Dominican Republic (Wooding and Moseley-Williams 2004).

The cane cutters were de facto prisoners; they were restricted to the bateys by the Dominican police force, constraining their civil rights, freedoms, and economic movement (Martinez 1999). In addition to the restrictive employer and police controls the Haitian Massacre of 1937, informed Haitians that bateys were the only safe location for them, therefore preventing the spread of Haitian laborers into other Dominican sectors (Martinez 1999). 
The Bracero program was designed as temporary program where Haitian immigrants would be returned to their country at the end of the sugarcane season; despite the stipulations an unknown number of Haitian laborers remained in the Dominican Republic without any difficulty. The deteriorating conditions in Haiti throughout Baby Doc's dictatorship motivated an increasing amount of Haitians to permanently settle in the Dominican Republic (Wooding and Moseley-Williams 2004).

The Dominican state failed to develop an administrative system documenting Haitian immigrants, giving most a document called a ficha, which indicated the Ingenio or sugarcane mill the individual worked for. With this document these individuals were able to document the birth of their children as Dominican citizens, in accordance with the interpretation of the Constitution and immigration laws of that time. The lack of a comprehensive immigration policy and no real means for naturalization has meant that there are generations of children born to undocumented Haitian immigrants within the Dominican Republic.

The "New Migration"

The fall of the Haitian Dictator Baby Doc in 1986 caused political and economic instability in Haiti, which led to the end of the formal labor contracts between the Haitian and Dominican governments (CEFASA/CEFINOSA 2012). Despite the end of formal labor contracts, Haitian labor still managed to cross the border to find employment opportunities. Haitian migrant laborers began finding their way over the border anaba fil or under the wire, and through agents called buscones on the Dominican side and smugglers on the Haitian side (Wooding and Moseley-Williams 2004:39). The transition from large scale formal labor contracts to the sugar industry to individual migration into 
diverse economic sectors is what Dominican sociologist call the "new migration" (Sillié 2005:10). The new migration began in the late 1970s and continues today. This migration has characteristics that differentiate it from the immigration of the past, one them being the shift in government participation and the reduction in control over migrant mobility.

The shift immigration patterns were accompanied by an economic shift in the Dominican economy. In the late 1970s early 1980s the Dominican economy was beginning to shift its focus from an agro-export model toward services, tourism, freetrade zones, and remittances (Sillié 2005). During this shift the sugar cane industry began to fail for a variety of reasons: sugar prices began to fall world-wide, the state failed to modernize its mills and the US decided to allow the sugar quotas system expire in the Dominican Republic (Wooding and Moseley-Williams 2004). The decline of the sugar industry had devastating effects for the Haitian laborers living in the bateys as the already abysmal conditions worsened under economic stagnation.

Haitian laborers began to leave the bateys to find that the construction industry along many agricultural sectors had high demand for cheap labor. As Haitians and Haitians of Dominican descent began to take advantage of more diversified economic opportunities they also becoming more visible in Dominican society (Wooding and Moseley-Williams 2004). The Dominican economy continued to diversify and expand in late 1980s through the 1990s while Haiti's economic situation continued to decline; motivating Haitians to continue to immigrate to the Dominican Republic. During this period an increase in Haitian migration was also motivated by worsening conditions in Haiti; natural disasters, political strife, and extreme poverty were pervasive in Haiti during this period (Kosinski 2009). 
The shift in both the Dominican and Haitian economies has caused the profile of migrants to change; the traditional migration of seasonal sugar or agricultural work restricted to a batey and determined by a government contract became a thing of the past. Haitian labor migration has now taken and individual nature with most immigrants entering and returning through the porous Dominican- Haitian border (Sillé 2005). Despite the high level of Haitian immigration and the increased demand for their labor power, the Dominican state has not develop a system of documentation or work visas to accommodate this influx of Haitian migration (Sillé 2005).

In the absence of a state sponsored system of immigration has resulted in $90 \%$ of the Haitian immigrant population in the Dominican Republic have an irregular immigration status (CEFASA/CEFINOSA 2012). The end of the formal labor contracts has also meant that Haitian immigrants have more mobility and are more visible in Dominican society than during the era when they were relegated to the batey. There is also a large population of Haitian immigrants living and working in urban areas of the country making them more integrated into Dominican society (Rosario and Ulloa 2006: 72).

The demographics profile of Haitian migration has also changed; while around $60 \%$ of Haitian migrants are men, contemporary migration has now included a higher number of women and families. There is also a growing class of middle class Haitians that are entering the Dominican Republic through formal immigration channels to attend universities (Rosario and Ulloa 2006). The traditional migration under the formal labor contracts was circular Haitians were brought in for the sugar season and then return to Haiti at the end of the season. This pattern of circular migration has continued 
independently, many workers continue to return to Haiti to see their family or bring remittances back (Rosario and Ulloa 2006).

During the era of the Bracero Program, Haitians were mostly absent from Dominican society as they were relegated to the spaces of bateys and the border; the "new migration" represented a shift in Haitian migration, mainly because it took Haitians from the dark holes of the bateys and brought them into mainstream society. With the collapse of the sugar industry and the subsequent diversification, mobility, and visibility of Haitians in the new migration, the Dominican state has become increasingly concerned with the Haitian presence. The lack of institutional attention to the issue of Haitian immigration for decades has resulted in the majority of this population in irregular immigration status. These conditions have worked to make the "new migration" extremely vulnerable to the Dominican state's immigration reform and retroactive citizenship stripping.

\section{The Haitian Profile}

There has been little investment by the Dominican state to understand the demographic make-up of the Haitian population or measure the economic contribution of Haitian migrant labor. The size of the Haitian population in the Dominican Republic has been a contentious topic that is inflated or minimized according to the interest of the party (non-governmental organization or political party) (Wooding and MoseleyWilliams 2004). The year 2012 was an exciting and active year for social and demographic research in the Dominican Republic initiated by private organizations outside of the Dominican government. 
This section will review the findings of these two major studies, and discuss the importance of the findings.

Both of these studies have significantly contributed to the understanding of the Haitian population within the Dominican Republic. These two studies form some of the only scientific data on Haitians within the Dominican Republic today. Therefore a profile of Haitians within the Dominican Republic will be developed.

First National Survey of Immigrants

Published in 2012, The First National Survey of Immigrants in the Dominican Republic (abbreviated ENI) was conducted in 2011 and ended in 2012. As the name alludes, this is the first ever census conducted that specifically investigated the demographics of the immigrant population within the Dominican Republic.

This study was conducted with the Dominican states' admission that its greatest weakness in regards to immigration is the lack of information on the immigrant population obtained through rigorous and systematic investigation (ENI 2012:25). The state received financing from the European Union and the survey was organized and implemented with the help of the United Nations Population fund in collaboration with the Dominican National Office of Statistics.

Below I will present some of the findings of this survey, especially the data concerning the number of immigrants in the country, their document status, and their economic status; all of the data below are derived from the ENI.

\section{Size of Haitian Population in the Dominican Republic}

The ENI defined immigrants as all individuals living and residing in a country that is not their country of birth. The survey was also interested in individuals born in the 
Dominican Republic and had either a mother or father who was not Dominican born. Within the methodology of the ENI they state that although they distinguish between these two populations, both categories are combined to be considered from foreign origin (ENI 201:15).

The data were collected using three different guided surveys which solicited information regarding basic information, living conditions and migration patterns. A representative sample of 68,0000 homes were visited in five different regions and agricultural zones where Haitian labor is most present in the Dominican Republic. Using this sample the researchers were able to estimate the make-up of the total immigrant population within the country. The research sample was comprised of 13,449 completed guided surveys with immigrants and 6,997 surveys conducted with descendants of immigrants, for a total of 20,446 completed interviews.

The study found that there are approximately 524,632 immigrants residing within the Dominican Republic, which is equal to $5.4 \%$ of the total population. Of the total number of immigrants $87 \%$ were born in Haiti, while $12.7 \%$ emigrated from 60 different countries. According to the study there are 244,151 descendants of immigrants residing in Dominican Republic, representing $2.5 \%$ of the total population. Of this number approximately 209, 120 are decedents of Haitian immigrants. The immigrant population is comprised of $64.4 \%$ men and $34.5 \%$ women and the $53.9 \%$ of this population is between the ages of 20 and 34 .

Based on the data collected regarding documentation, $92.6 \%$ of Haitian immigrants were in possession of a Haitian birth certificate and $37.8 \%$ also possessed a Haitian passport. This is compared to $89.5 \%$ of immigrants from other countries that 
possessed both a passport and a birth certificate. Only $55.3 \%$ of the descendants of Haitian immigrants possessed a birth certificate, and 23.5\% possess a Dominican cedula, the Dominican national identity card.

The data from the ENI demonstrate that the overwhelming majority of immigrants in the Dominican Republic are Haitian or from Haitian descent, approximately $87 \%$ and they make up $7 \%$ of the total population of the country. The number calculated by the ENI is actually close to the estimates that have been made in previous years, usually ranging between 400,000 to 800,000 Haitians in the territory (Bartlett, Jayaram, and Bonhomme 2011) while political estimates have estimated as high as 1.5 million Haitians in the DR, accounting for nearly a tenth of the D.R.'s population (Howard 2001; Mathae 2011).

The majority of Haitians immigrants have some form of Haitian documentation; a birth certificate or passport. Only half of the descendants of Haitian immigrants have a birth certificate, this means that the other half have no form of identity documentation. Because they grouped those who had one immigrant parent with those who have both immigrant parents, we are unable to tell how many of these individuals will be affected by the immigration reform and the decision of the Constitutional Court.

Apart from the demographic information, the survey inquired about living and work conditions, access to healthcare and education which revealed that Haitian immigrants live in extreme poverty without basic amenities such as running water. Haitian immigrants also have little access to medical and educational services, and do not feel they have anywhere to report labor abus0es such as withheld of pay. 


\section{Economic Impact of Haitian Migrant Labor}

Many institutions within the Dominican government have made the claim that the Haitian presence in the Dominican Republic is one of the main reasons the Dominican Republic has had sub-par advances in development and in reaching the Millennium goals the (CEFASA/CEFINOSA 2012). Data supporting these claims, or analyzing the impact or costs of the Haitian presences has been largely non-existent.

The Center for Social Action and Agrarian Training (Centro de Formación y Agraría: CEFASA) and the Firm of Economic, Financial and Organizational Consultants (Consultores Económicos Financieros y Organizacionales: CEFINOSA), published a ground breaking study on the presence of Haitians in the Dominican Republic called The Condition and Contribution of Laborers of Haitian Origin in the Dominican Economy. The main objective of this study was to evaluate the cost and benefits of undocumented Haitian labor in the Dominican economy in an attempt to contribute to the debate on Haitian migration.

The data responds to three main arguments: Haitian immigrants raise the level of unemployment; they reduce salaries by accepting lower pay; and they reduce the quality of social security by being a burden on the medical and education system.

This study used a number of different research methods; they conducted focus groups with the employers, managers, and union leaders of the five major industries that predominantly use Haitian labor. The study also included document analysis, interviews, and surveys of employers, government official, and employees both Haitian and Dominican (CEFASA/CEFINOSA 2012:20-21) 
According to the study, Haitian and Haitians of Dominican descent represent a majority of laborers in the DR economy's most influential sectors of rice, coffee, sugar, banana, and the construction industry. Haitian labor represents $64 \%$ of the workforce in these agricultural industries and $13 \%$ in other sectors, with a breakdown of the percentage of workers as: rice $80 \%$, coffee $80 \%$, sugar $90 \%$, banana $70 \%$, construction $90 \%$; less than $1 \%$ of the workers in all of these sectors combined have regular status.

Haitian labor has filled the labor needs created by the internal migration and emigration of Dominicans. The Dominican Republic has experienced rapid urbanization and around $70 \%$ of Dominicans live in urban areas while only $30 \%$ of Dominicans live in rural areas. As much as 5\% of the Dominican population has emigrated to the US and to other countries, leaving a labor deficit in the agricultural sectors (CEFASA/CEFINOSA 2012:17).

One of the most prominent arguments in the immigration debate is that Haitian laborers displace Dominicans in the job market; despite this popular belief the study found that Haitian migrant workers actually contribute to job creation as Haitian laborers function as reinforcements and replacement laborers to industries in which there is a shortage of local workers due to emigration, poor working conditions, or low wages (Sillié 2005:10).

Haitian migrant laborers usually occupy low skilled labor positions, leaving more skilled positions for Dominicans; therefore the labor of a Haitian migrant worker and Dominican are not substitutes (CEFASA/CEFINOSA 2012:137).The availability of cheap Haitian labor power has allowed the sectors dominated by Haitian labor to remain competitive despite failures to invest in modernization and technology 
(CEFASA/CEFINOSA 2012: 231).

The proportion of Haitians working in these sectors is actually against the General Migration Law285-04, Article 135 which states that all business with more than 10 employees must maintain a 80:20 proportion of Dominicans to foreign workers (CEFASA/CEFINOSA 2012:17). In focus groups conducted with the producers of these industries it was found that employer compliance with the 80:20 stipulation would paralyze their businesses, as the reality of the proportion is more closely reflected in the opposite- there are about $80 \%$ of Haitian workers and only about $20 \%$ of Dominican workers (CEFASA/CEFINOSA 2012:144). The application of this law would also have important implications for the Dominican economy as a whole if the major Haitian labor industries collapsed, a loss of about \$2,598,228,000 Dominican Pesos or 9.30\% of the nation's GDP (CEFASA/CEFINOSA 2012:144).

The availability of a large pool of Haitian migrant workers allows prices to remain stable when the price of inputs increases, therefore contributing to the overall growth of the economy. All of the sectors that most rely on Haitian labor experienced a notable growth between 2006 and 2010 - this was the case for exports as well which had a 118\% increase between these years as well (CEFASA/CEFINOSA 2012:144). The conclusion of the study emphasized the positive contributions of Haitian labor:

The comparison between the benefits and costs of the use of the labor of Haitian descent to the Dominican economy, either regular or irregular, yields positive results, i.e. the contributions that make workers far outweigh the social costs they generate (CEFASA/CEFINOSA 2012: 275) (Translation mine).

The social costs that undocumented Haitian workers incur are the costs associated with free primary education (a benefit that came through international pressure), and 
medical services. The study's analysis of the cost- benefit analysis demonstrated that Haitian labor presents a $30 \%$ benefit to their social costs in comparison to their economic contribution (CEFASA/CEFINOSA 2012:143).

The study calculated the number of Haitian laborers and the minimum wage established by the state and found that Haitian laborers currently produce five times more than the state has paid in services for these undocumented workers (CEFASA/CEFINOSA 2012). The costs of the services that social security law pays, specifically medical, will never surmount the income that the laborers bring in, especially because many of these immigrants do not use public services out of fear or ignorance.

As mentioned before, Haitian labor represents $64 \%$ of the labor in the five most important Dominican economic sectors, of this $64 \%$ only $1 \%$ have regular immigration status. The irregular status of these immigrants has been problematic for immigrants, but also represents a problem for the state. Without a cohesive plan for regularization or documentation for Haitian immigrant workers, they benefit from public social services such as health care and education without the means of contributing to the Dominican social security system (Sillié 2005:11).

According to the study, if the state was able to capture their contribution to social security it would be approximately RD $\$ 2,034$ million pesos - which would cover the costs that the state incurs in medical costs and education, and could potentially provide these laborers a retirement (CEFASA/CEFINOSA 2012). The study had determined that in all sectors in which Haitians work, giving Haitian workers regular status represents a benefit not a cost. 
Based on the results of this study it is undeniable that Haitian labor is a major contributor to the Dominican economy, according to the study "The presence of Haitian nationals in the Dominican Republic is a reality and an unquestionable necessity" (CEFASA/CEFINOSA 2012:51). Irregular Haitian labor has allowed for the growth of the Dominican economy; the low wages, poor working and living conditions have buffered the cost of modernization or regular labor. This study then provides insight into the Dominican state's continued anti-Haitian politics; it relies on Haitian labor, but needs this labor to remain vulnerable and disposable. 


\section{CHAPTER IV METHODOLOGY}

Analyses of the Dominican Constitutional Court Sentence 168-13 in the media and by human rights organizations have asserted that the basis of the law is racial discrimination. While discrimination may be a contributing factor to the creation and implementation of the sentence, these analyses may overshadow the instrumental role of law in the production of migrant illegality. In regards to the analysis of the production of illegal populations DeGenova asserts:

Without engaging in the unwitting apologetics of presumptively characterizing the law's consequences as "unintended" or "unanticipated," and without busying ourselves with conspiratorial guessing games about good or bad "intentions," the challenge of critical inquiry and meaningful social analysis commands that one ask: What indeed do these policies produce? (DeGenova2004:179)

DeGenova's position is that understanding migrant illegality and enforcement requires us to critically examine immigration law to understand how they produce their subjects.

This research is a historical case study, which examines five key pieces of legislation in the immigration reform, including the very recent Sentence 168-13. The objective of the study is to analyze the Dominican state's legal actions within the greater socio-historical context of the Dominican Republic. The previous examination of the 
literature has outlined the relationship between Dominicans and Haitian immigrants, the Dominican ethno-racial formation, and the economic significance of Haitian laborer within the Dominican market. This information will inform the following analysis and allow for socio-cultural and historically informed inferences about the construction of Haitian illegality.

\section{$\underline{\text { Analytical Tools }}$}

\section{Hermeneutic Analysis}

The ultimate goal of the research is to create a narrative that infuses the contextual information with the data collected to construct a more complete picture of the immigration reform. Constructing a narrative is an interpretive endeavor, which requires an interpretive approach to the collection and analysis of data. Therefore I have adopted an interpretive hermeneutic approach that will guide my analysis.

The hermeneutic tradition follows the understanding that meaning is not fixed or predictable but rather social phenomena need to be understood within a socio-cultural context (Myers 1997). From the perspective of hermeneutics, multiple social realties require a description of social phenomena that is derived using a variety of tools and through an examination of patterns, relationships, and flow of events (Patterson and Williams2002:15). A sociological hermeneutic analysis attempts to understand the social action or events through contextualization combined with an understanding of what the action means to the participants or the culture involved, this is what Anthony Giddens (1967).referred to as double hermeneutics.

This study's analysis aims to shed light on the seemingly contradictory nature of the Dominican state's legal stance and actions regarding Haitian immigration, and to 
examine the study's assertions about the state's motive. I will analyze the legal documents individually, in conjunction with other legal documents, and then interpret them within the greater context established in the literature review. This kind of analysis is comparable to the hermeneutic circle, where there is a dialect between understanding the social phenomena as a whole through an interpretation of its parts (Myers 1997). Guiding my interpretation and analysis are the tools of historical analysis, theory, and personal experience as a data collection tool.

\section{Historical Analysis}

Historical analysis is the study of the relationships between the issues that have affected the past and influence the future; it also seeks to establish meaning between events and their ideological, social, and economic influences (Berg 2009). This study is a historical analysis as the examination begins with an analysis the Immigration Law of 1939 and ends with the most recent legislative development in the immigration reform. The historical analysis is meant to understand the historical and gradual construction of Haitian illegality and deportability, which has ultimately resulted in the stripping of citizenship of Haitian descendants. Experience of the Researcher

The relationship between Dominicans and Haitian immigrants, along with the real implications of the immigration reform on the lives of Haitians and their descendants are both issues that I have become personally familiar with. As a United States Peace Corps Volunteer I lived and served in the Dominican Republic from August 2010 to October 2013. I served as a community economic development volunteer on the eastern part of the island in Ingenio Consuelo, in the province of San Pedro de Macorís. 
The eastern region of the country was at one time one of the major sugarcane producing regions in the Dominican Republic. Ingenio Consuelo is the home of a sugar cane mill, which produced sugar from the 1800 s to the late 1990 s. The mill was the center for the surrounding settlements for Haitian laborers called bateys, where thousands of Haitian laborers were brought from Haitian to labor in the sugar cane. During the sugarcane heyday, many Haitians stayed in the Dominican Republic and began families. The collapse of the sugarcane industry left many Haitians seeking better opportunities closer to Consuelo. The community where I lived was called Barrio Filiu, and was created as a result of Haitians escaping the desolate conditions of the bateys and squatting the unused sugarcane.

Barrio Filiu was composed of individuals who were descendants of Haitian sugarcane workers, recently immigrated Haitians, and to a much smaller extent Dominicans. Living in this community gave me an interesting insight into the lives of Haitian immigrants, but also the dynamic between Dominicans of Haitian descent and recently immigrated Haitians. As I worked with community groups in this community I unwittingly became a spokesperson for their rights to enroll their children in school or receive the civic attention that the community deserved.

In my last year of service in 2012, I became the Volunteer leader and trainer for the community economic development sector, which required that I traveled extensively throughout the country to visit volunteers and scout potential new volunteer sites. Through my experience traveling to different parts of the country I had the opportunity to see first- hand how antihaitianismo functions within different regions of the country. On three separate occasions my documentation was questioned, and once coming back from 
the southern-most part of the country I was pulled of a bus and asked to verify my documentation.

Hermeneutic understanding holds that interpreting and understanding means a researcher will use their own preconceptions in order to make meaning clear; therefore two researchers may interpret a situation differently based on their background knowledge (Giddens 1976). My experiences living in the Dominican Republic have helped me develop a framework of understanding that informs my research and my interpretation of the state's actions.

\section{$\underline{\text { Research Design }}$}

The main research method employed is a qualitative historical document analysis using five key pieces of legislation regarding the immigration legislation in the Dominican Republic. While document analysis has been overlooked as a primary qualitative method for surveys or in-depth interviews (Berg 2009), document analysis within this context has provided valuable insights into understanding the legal details of this situation. The tenuous historical relationship between Dominicans and Haitian immigrants has tended to take center stage, leaving the legal production of migrant illegality understudied.

Documents and especially legal documents have a concrete or semi-permanent existence, which tells us indirectly about the social world of the people who created them (Payne and Payne 2004). The use of the legal documents allow for a tracing of the historical creation of illegality and deportability without the need to rely on human memory or without invoking biases that may accompany the understanding of the Haitian migration situation in the Dominican Republic. 
A method of document analysis also provides and unobtrusive and non-reactive method for analyzing a highly sensitive situation. The recent sentence of the Constitutional Court has inflamed the issue of Haitian immigrants in the Dominican Republic and has revived ideological stances on what it means to be Dominican. Unobtrusive measures can allow a researcher to examine how humans are affected by ideological stances (Berg 2009).

\section{Data Collection}

Throughout the research I have frequently referred to the immigration reform as a series of laws, memorandums, court decisions, and constitutional changes beginning in 2004 these pieces of legislation compose the buildup that has led to the development of the drastic Constitutional Court Sentence. Due to the scope and limited resource of this project, I have limited the analysis to five of the major pieces of legislation to analyze as primary sources of data, the documents used for this analysis consist of:

Immigration Law 95 of 1939

Regulations and Procedures 279 of Immigration Law 95

General Migration Law 285-04 of 2004

Regulations and Procedure 631-11 of 2011

Constitutional Court Sentence 0168-13 of 2013

All of the documents analyzed are public information and by law are published in the government gazette that can be accessed in person, and to some degree through the internet. I was able to collect these documents from a variety of governmental websites. The documents are also available through many legal and human right organization websites. 
The analysis of the documents will be accompanied by an introduction that legally and historically contextualizes the document, containing information on important pieces of legislation that were not analyzed here. The discussions preceding the actual analysis of the law are derived from secondary sources. The secondary sources are mainly composed of legal studies and observations in studies commissioned by non-profit and human rights organizations which have followed the history of the legal changes. Process of Analysis

The documents underwent several layers of analysis. The first level of analysis was concerned with comprehension of the text and identifying the areas of the text that related to areas of concern. Each documents contained large amounts of information, some of it not relevant to the focus of the study. I therefore translated the documents, paying particular attention to the areas concerning the chosen areas of focus, with the intention of representing these areas as truthfully as possible. I began by translating the documents and conducting a qualitative description of the elements in the document looking specifically at the manifest meanings of the three topics of concern.

Qualitative description uses a method of low-inference, meaning describing the phenomena in everyday words with avoiding more interpretive understandings (Sandelowski 2000). While using qualitative description researchers stay close to the data and the surface of the words, and avoid interpretations (Sandelowski 2000). Legal documents can be difficult to understand, this can be doubly complicated when examining legal documents in a different language. Therefore this preliminary level of analysis produced data that was coherent and intelligible for further analysis. 
The second layer of analysis involved sorting the documents into common topics or themes that were common in the documents and aided in answering the main research objective. I developed three questions that helped organize and focus the data:

1. What are the requirements for legal status and who is entitled to citizenship and/or legal status within the Dominican Republic?

- Are these constructions of legality prohibitive for Haitian immigrants and their descendants?

2. How has the Dominican state historically legally constructed migrant and specifically Haitian illegality?

- How has this definition shifted or changed through history?

3. How has the Dominican state worked to legally define Haitian immigrants as a workforce?

- What have been the methods and tactics the state has used in order to create the category of non-residents in the Dominican Republic?

In addition to the analytical questions, I included an analysis of the definition of in-transit has been through the laws. The in-transit clause is important as it has been used in later legislation to retract citizenship from Haitian descendants. Therefore the changes in this clause will be examined throughout the analysis of the different laws. 


\section{CHAPTER V}

\section{ANALYSIS OF THE DATA}

\section{Analysis of Migration Law 95 of 1939 and Regulations and Procedures 279}

The first immigration law that regulated immigration in the Dominican Republic was Migration Law 5074, created in 1912 (Centro Bonó 2011). This migration law was basic and stipulated that the Dominican Republic was open to all individuals that were civilized and of good character, except for those that were mentally or physically ill and were not from the Caucasian race (Centro Bonó 2011).

Between 1912 and 1939 there were various changes to the immigration law, the most important being the admission of non-Caucasian temporary workers in 1927 (Centro Bonó 2011). Law 5074 was replaced by Immigration Law 95, passed in April 14, 1939 and its accompanying Law 279 Regulations for Procedures. These two laws further established the conditions for the entry for temporary workers, the only way in which Haitians were able to legally enter the Dominican Republic during that time period.

The 1939 law was passed under the dictatorship of Rafael Trujillo and two years after one of the darkest historical periods in the relationship between the Dominican state and Haitian immigrants; the 1937 Haitian Massacre. This massacre was responsible for the deaths of tens of thousands of Haitians, but is also recognized as the beginning of Trujillo's ideological mission to nationalize the borderlands through the promotion of 
antihaitianismo (Turits 2002).

Following the massacre Trujillo began to promote the idea that the presence of Haitians in the country and especially on the borderlands formed part of a "pacific invasion" of backward and savage black Haitians (Turits 2002). Haitians residing within the already oppressive sugar cane plantations were spared in the massacre; indicating that the only safe place for Haitians were the oppressive sugar cane plantations (Martinez 1999).

The historical context helps inform the analysis presented below of Migration Law 95 of 1939 and Law 279 Regulations and Procedures. I analyzed these two pieces of legislation together as the Law 279 works as detailed procedural documents meant to aid in the implementation of Law 95.

How is Legal Status Constructed?

Article 3 of Law 95 divides all foreigners wishing to enter the country into two different categories: immigrant and non-immigrants. Therefore there were only two categories in which a foreign individual can enter the Dominican Republic, as an immigrant or a non- immigrant. The article states that all foreigners will be admitted under the category of immigrant except for the case of students; individuals in-transit to another country; crewmembers of transportation; and temporary laborers and their families (p.2). The individuals in this list will be considered non-immigrants, according to the article.

The conditions to classify under the category of immigrant seem fairly lax; the requirements for immigrant status include the possession of a valid passport or identity documentation and the successful application for a residence permit (p.2). The 
paragraph following Article 3 states that all immigrants are eligible for indefinite stay within the territory, while non-immigrants have temporary admission and are subject to regulations stipulated in the Regulations 279.

Those who do not qualify for immigrant status are outline in Article 3 as individuals in- transit, and temporary migrant workers. Article 10 contains an additional list of individuals who would not qualify for the immigrant status; this includes anarchists, vagrants, unaccompanied women or children, previously deported individuals, and the mentally or physically ill (p.5).

Included in the non-immigrant status is the category of temporary migrant worker. The paragraph following Article 3 stipulates that the entry of temporary workers is contingent on an agricultural business that has solicited their employment. This article also stipulates that temporary workers will be subject to the surveillance of the Secretariat of the State of the Interior and Police, who will monitor their monitor their entry, stay, and repatriation.

Immigrants, according to Article 5 were eligible to apply for a permit of residence, which needed to be renewed annually, but could be validated for an indefinite period of time. The entry and stay of the temporary migrant worker is contingent on the offering of work, and the mechanism of surveillance from the state (p. 3).

Due to the very basic differentiations between the two immigration categories we can discern that difference between immigrants and non-immigrants, was easily discerned. The Dominican Republic was basically open to any socially acceptable category of individuals, except temporary laborers and those in-transit; basically all individuals except Haitians. 
We know from the historical review that the climate for Haitians during this time was such that Haitians were welcome in the Dominican Republic, except for those that were working on the sugar cane plantations. We can infer that the law's stipulation that temporary workers and their families are ineligible for immigrant status would have been directed at this population.

\section{Migrant Illegality and Deportability}

Article 13 (p.8) outlines the conditions under which foreigners could be deported. The article states that anyone who entered into the territory with false documents, evaded immigration authorities; the overstaying the provisions of a visa; individuals deemed ineligible for entry; or an individual without permission to legally reside permanently. or anyone who is deemed ineligible for entry outlined in article. This article establishes the framework for migrant deportability.

One of the interesting characteristics of this law is that it does not explicitly define migrant illegality. It gives a brief outline of individuals who were eligible for deportation but does not state explicitly that any of these individuals will be considered to be illegally residing. Therefore we get the sense that there was not a trend of criminalization of immigrants.

\section{In-transit Clause}

Section V of Regulation 279 discusses transitory or foreigners in transit. In-transit here is defined as foreigners with the principal purpose of traveling through the country to arrive at an exterior destination are considered transitory. A period of ten days is considered an appropriate amount of time for these individuals (p. 4). 


\section{Migrant Labor}

Migration Law 95 does not explicitly detail the conditions of the entry and stay of temporary migrant labor workers, but this task is done in section VII of the Regulation 279 (p. 4).The section states that temporary laborers and their families were able to the Dominican Republic under the contract of an agricultural business or organization. This section is directed to the employer, who, according to the section carries a large amount responsibility to the state in regards to the supervision and especially the repatriation of the workers.

The employer who would like to contract temporary workers is required to fill out an application which requires information regarding the number of workers, their nationality, the date and location of the entry of the workers, and the date and location of the repatriation. The employer must assume all responsibility for the entry and exit of all the temporary workers, and is required to ensure that the workers actually cross the border at the time they are repatriated. When the laborers enter the country the employer is responsible for submitting a list of all the laborers including four photos of each employee to the Secretariat of State of Interior and Police ( Regulation 279: 4-5)

In addition to the large amount of administrative requirements the employer must comply with, there is also a fee that the employer pays for the laborers. The workers are paid for by each group of worker, the price stipulated in the Regulation is one thousand Dominican Pesos for each 50 people; today this would equate to around twenty-five US dollars, no indication if this price was raised for inflation throughout the years the law was active. Each individual laborer and their family members were also required to submit an application and pay a fee for temporary labor card. 
The amount of administrative paperwork, the fee for each immigrant, and the responsibility for the entry and repatriation of each laborer may have presented a heavy burden or a deterrent for employer. This burden may have deterred the continuation of continued use of labor contracts. Despite the abandonment of the labor contract system, the stipulations regarding temporary laborers were active until 2004. A review the immigration law demonstrates that unless Haitian immigrants were admitted to the country under the temporary migrant status, they therefore entered the country illegally or under an irregular status.

\section{Summary}

A review of this piece of legislation shed some insight into why $90 \%$ of Haitian laborers are irregular today. The law's stipulations of legal residence do not provide Haitians with any realistic options for documented entry. The sugarcane industry is one of the only industries that used the labor contract system, through bilateral contracts with the Haitian and Dominican government. These last of these contracts was made in 1986; the collapse of the sugarcane industry coupled with the political instability ended the bilateral government contracts (Wooding and Moseley-Williams 2004). The use of Haitian labor after the end of the contracts continued and began to diversify, but one of the major differences was the individual entry of Haitian migrants without large formal labor contracts.

The large number undocumented Haitians in the Dominican Republic accompanied with the high percentage in the workforce informs us that this law was not strictly followed, or enforced. The law does not include a process through which 
temporary laborers could become residents or regularized through long-term residence. So there are no realistic options for Haitians.

There is nothing in the law that prevents Haitians from applying for entry under the immigrant status; yet the fact that $90 \%$ of Haitians are without any form of documentation informs implicitly tells us that this has not been a viable option. The Centro Bonó, a Jesuit group that works in advocacy and research regarding the Haitian phenomena in the Dominican Republic has found that the application process for residence includes high costs and difficult requirements for Haitian immigrants (Centro Bonó 2011). In their advocacy work they also found that several administrative attempts at regularizing status by Haitian immigrants was met with prejudice and resulted in delayed or never processed paperwork (Centró Bono 2011).

Although this law was written in 1939 an analysis of this law is important because it was the law that regulated migration until 2004; meaning that all of the Haitian immigrants who entered the Dominican republic between 1939- 2004 were subject to these laws.

Analysis of General Migration Law 285-04 and Regulations and Procedures 631-11

On July, $21^{\text {st }}$ of 2004, the state passed the General Law on Migration 285-04, replacing the Migration Law 95 of 1939, becoming the state's most comprehensive reform of immigration statues in sixty-five years (Open Society Justice Initiative 2009). This law made dramatic changes to the existing immigration policies, and is four times longer than the previous legislative document.

The introduction to Law 285-04 begins with considerations on which the creation of the law was based. The discussion begins with an acknowledgement of the importance 
of immigration to the Dominican Republic, and is followed by lengthy considerations which list human rights agreements and international pacts, regarding the countries obligations to human rights and refugees. This is an interesting way for the law to begin; it implies that Dominican state is aware of their responsibility of their membership within the international community, and their obligations to uphold conventions and agreements they have entered into.

The analysis of the General Migration Law will be conducted in conjunction with an analysis of the Regulations and Procedures 631-11. The document, Regulations and Procedures 631-11, works in conjunction with the immigration law in order to outline the details of how the General Migration Law should be enacted. Many of the articles of the General Migration Law reference the Regulation in outlining how it is to be applied; therefore the Regulation is an integral part of the implementation of Law.

Although Article 153 of the General Migration Law, states that the Regulation was to be passed 180 days after the passage of the General Migration Law (p. 46), the Regulation was not passed until June of 2011, almost seven years after the 2004 passage of the General Migration Law. Many articles and statements in the General Migration Law were not fully elaborated until 2011, and still today many of the institutions and regulations within the law have yet to come to fruition. Below is an analysis of both documents and how they relate to the research questions of the study.

\section{How is Legal Status Constructed?}

The 1939 Migration law only contained two categories in which immigrants could be admitted into the country, the categories of immigrant and non- immigrant. Article 29 of the General Migration Law redefined these categories by creating two new categories: 
resident and non-resident (p. 19). Article 31 divides the category of resident into two different categories; permanent residence a stay for an undefined amount of time, and temporary residence which is a stay of a defined period of time (p.19).

The qualifications for admittance under the permanent resident category are outline in Article 33 of the General Migration Law (p. 20) include: individuals with professions or occupations considered valuable to the development of the country; investors who are prepared to invest a fixed amount of their wealth established by the regulations; and foreign relatives of Dominican Nationals.

Understanding the basic characteristics of Haitians immigrants and their offspring within the Dominican Republic, we know that they have low education levels and are amongst the poorest individuals in Dominican society. They would therefore be unlikely to qualify for the professional or investor category of permanent residence. There is no category for permanent residence for individuals that have resided in the country for a long period of time. Therefore the category of permanent resident is out of reach for most Haitian immigrants.

Article 32 (p.19) defines a non-residents are foreigners who do not plan to settle in the country, Article 36 (p.22)breaks the category down into the subcategories of: tourist, business people, crewmembers, individual in-transit to another location, tourist/academic/athletic groups, temporary workers, and habitants of the frontier. Temporary workers are understood to be workers that enter in the country individually or with a group under a contract in accordance with the quota system (p. 23).

The majority of Haitian immigrants would fall under the category of temporary laborer, yet this sub-category does not necessarily fit this population either. The sub- 
category of temporary worker requires a labor contract and to be recognized by

responsible authorities. The majority of Haitians residing in the Dominican Republic did not enter through a large scale labor contract, and therefore these individuals are left out of any legal way to define their status in the country. The category of temporary migrant worker does not fit the reality of neither Haitian immigrants nor the industrial organizations who would hire them.

Article 150 of the General Migration Law appears to acknowledge the large population of long-term residing Haitian residents, as it stated that the General Directorate of Migration will develop a national regularization program for long-term residing irregular immigrants (p. 45). Article 150 of the migration law states that the law will renew the permits of those who entered the country under the Law 95 of 1939 under the new subcategories outlined in this law. Article 151(p. 45) continues to states that the Dominican government must establish the National Plan of Regularization for individuals who have resided within the territory for an extended period of time. The plan would consider several different aspects such as immigrant socioeconomic status, networks and connections within Dominican society and work conditions. Despite the high hopes for this plan, today at the end of 2013, this plan has yet to be developed.

\section{Migrant Illegality and Deportability}

From the beginning of the General Migration Law, Article 2 states that the immigrants within the national territory are regulated with the aim that all foreigners will be under the condition of legality in the country (p. 10). The article stipulates that all individuals who are eligible for entry and stay in the country will receive the corresponding documentation that authorizes the condition and their migratory category; 
this documentation is compulsory. The last sentence of this article states that Illegal foreigners will be rejected from the national territory.

Unlike in the 1939 Law, the General Migration Law explicitly outlines conditions under which immigrants could be considered illegal from the beginning. This article makes it clear that the purpose of the law is to ensure that all individuals within the territory have legal status.

Illegality is mentioned several times throughout the Law and under many different sections which outline the different pathways through which individuals can become illegal. In Article 8 number 8 (p. 12) states that the Secretary of State of Interior and Police (SSIP) in conjunction with the General Directorate of Migration can declare all individuals illegal when they cannot provide the necessary documentation declared compulsory in article 2. Article 13 and 14 (p. 13-14) grant the SSIP authority to enter places of work and public transportation in order to conduct inspections of documentation. Articles 65-68 (p.28) outline the modes of entry that would classify an individual as illegal; all foreigners must enter through the designated ports of entry. Entry through non-designated areas, the use of false documents, or evading immigration authorities all classifies individuals as illegal; those who enter illegally will be subject to deportation.

One of the most drastic changes the General Law outlined was the end of birthright citizenship for immigrants, despite the jus soli right to citizenship outlined in the Constitution. Article 28 of the General Migration Law (p.18) and article 36 of Regulation 631-11 (p. 19) state that if a foreign mother has a child in the country she is to register the child at the consulate of her country, unless the child's father is Dominican in 
such a case the child could be registered at the Dominican administrative office for citizenship. Non-national mothers are all to receive a pink certificate of live birth rather than a birth certificate; which does not confer citizenship or a nationality. The article also stipulates that all births of foreign mothers are to be registered in the book of foreigners with the SIPP and the Central Electoral Board so they are able to note that the infant is not eligible for citizenship.

The Regulations and Procedures 631-11 continues the discussion of children born within the territory to foreign mothers, but moves to elaborate the disciplinary actions for the medical staff and center where infants are born. In addition to the requirements for reporting the birth and information of both the mother and child, Article 37 of the Regulations and Procedures (p.19) states that if a women who gives birth does not have a passport or any documentation she is to be reported by the medical center to the Inspector of migration so that the necessary investigation could be conducted. Article 39 and 40 state that the Directorate of Migration and the SIPP have authority to conduct inspections of medical centers to ensure that they are complying with the law; centers or individuals found in non-compliance will be subject to arrest.

In regards to deportability, the law spoke several times about who was considered illegal and that they were subject to deportation. In addition article 151 of the General Migration Law (p. 45) and Article 136 of the Regulation (p. 69) reiterate that the General Directorate of Migration orders the deportation of all individuals who: entered the country clandestinely, used falsified documents, overstayed their visa, and anyone who falls under article 15 (mentally/physically ill, prostitutes, criminals, and previous deportees). 
This regulation largely impacts Haitian immigrants as they are not only the largest foreign population in the Dominican Republic but also have the highest percentage of undocumented immigrants. The regulations regarding the birth of babies to foreign mothers contributes greatly to the vulnerability of this population. Primarily by not granting the infant citizenship, the infant is reliant on the mother's citizenship. If the mother does not have documents, from either Haiti or the Dominican Republic because her parents did not have the necessary documents to declare her a citizen, then the infant inherit s the mother's stateless status. The regulation also requires medical personal to become an extension of the law and of enforcement practices as it forces them to report women without documentation. This increases the vulnerability of women in an already vulnerable state.

In-transit Clause

One of the changes that has had the largest impact and has garnered the most attention in regard to the General Migration Law is the change of the definition of what in-transit means. In-transit as defined in the 1939 migration law was considered anyone traveling through the country for a period of ten days on their way to another destination; this category also included diplomats and tourist.

Number 11 of Article 36 (p.21) in the General Migration Law states that all who are fall within the non-resident category are to be considered in-transit for the purposes of article 11 of the Constitution. Article 68 of Regulation 631(p.32) contributes to this new definition, stating that all non-resident foreigners and foreigners who entered the country illegally are considered to be in-transit. 
These delimitations of the in-transit clause are very important because article 11 of the Constitution outlines who is eligible for Dominican citizenship. Before the constitutional change all individuals who were born within the Republic were considered

nationals, except for those in-transit. The new definitions basically state that anyone who is not a resident is basically in-transit.

The in-transit definition of the 2004 migration law disproportionately affects Haitians, due to historical discrimination, it has always been difficult for Haitians to retain the identity documentation necessary to become legal residents of the Dominican Republic. The in-transit definition change makes it so that children will be ineligible for citizenship, regardless of how long their parents or grandparents have been in the country. Migrant Labor

The Law clearly acknowledges that immigration is an important component to the Dominican economy. Article 3 of the General Migration Law (p. 10) states that immigration is to be planned and controlled in order to incorporate the human resources necessary for the development of the territory. This refers to Haitian laborers as this is the only group of laborers in this country.

The process for the entry of temporary migrant workers is very similar from the process that was outlined in Law 95. According to Article 95 (p.32) the National Council of Migration (an organization created by the General Law) is to establish a quota of temporary workers who will be admitted into the territory annually. This quota is to be determined with consultation from labor unions, the business and agricultural sectors. Based on this quota workers can be contracted according to the needs of the sector. 
Similarly to the 1939 Law, employers are able to go through a paperwork heavy process in order to contract temporary laborers in their field. In addition to paying the costs for the entry and exit of the workers the law requires that the employers also place a deposit guarantee for each worker. In addition to the administrative requirements the law adds new restrictions and penalties for employers who would use migrant laborers.

As mentioned before use of the large scale contract system has been rare since the 1980 's; today only in the banana sector is currently employing large scale contracts in compliance with the law. The requirements for following the law are very prohibitive for employers and the application process is unrealistic for most Haitian laborers. There is a high cost associated with employing the contract system: there is an application cost, the cost of transport for entry and exit of each immigrant, and a deposit for each laborer. In addition to the high costs of entry Article 53 (p. 26) states that if a laborer becomes ill or physically inept the laborer shall be sent back to the country of origin at the cost of the employer. If the employer does not comply with any of the regulations outlined in the law or the regulation, Article 131 (p. 41) states that the contractor can be fined anywhere from three to ten minimum salary for each infraction.

In addition to the application process of the employer, Article 70 (p. 32) of the Regulation states that each laborer must also go through an application process which involves pictures, copies of their passport, a certificate of good health from a doctor, and health insurance. While these requirements may seem innocuous on the surface they are difficult for individuals of very little resources and education; the documentation is most likely in Spanish and the process is highly bureaucratic and difficult. 
The structure of the temporary worker status places a lot of control in the hands of the employer over the immigrant. The employer is responsible for the immigrant, and has made a large investment in order to have the laborer, and could potentially be subject to penalties depending on the actions of the laborer. There is a concern that this structure could produce a situation of un-free labor, where the laborer represents a commodity and the employer is in a dominating and controlling position of protecting their investment.

According to Article 56 (p. 26) the laborers receive cards they must keep on them at all times that in addition to their basic information include who their employer is, what area of the country they should be in, and the duration of stay. This allows immigration enforcement to return laborers to the area they be in and determine the legitimacy of their entry into the country. The structure of the program seems precarious for the civil rights of these individuals and could produce conditions similar to the abysmal situation of the sugarcane bateys. For now we can only make assumptions about what the situation would look like in actuality; despite the fact that it is the ruling law it has not come to fruition nor is strictly enforced.

Haitian laborers are made vulnerable by their immigration status; they are vulnerable to migration authorities, but also vulnerable to employers. Article 22 of the General Migration Law (p. 18) stipulates that all legal foreigners are entitled to civil rights and Article 26 states that all legal foreigners are entitled to labor protections. From the research we know that from the beginning of the entry of Haitians as laborers in the sugarcane industry Haitian immigrants were deprived of most civil and labor rights. Today this is still the case as the law demonstrates; Haitian laborers are not entitled to rights. 
The sanctions regarding both migrants and employees are such that if implemented it would be difficult for Haitians with irregular status to acquire work. According to Article 101 (p.32) foreigners that are illegally residing $n$ the national territory can under no circumstances engage in remunerated work. Article 102 (p. 32) states that all employers are to verify that workers have legal status in the country. Article 132 (p. 34) states that any employer contracting illegal workers will be charged a penalty of five to twenty minimum wages; Article 104 (p.) states that the employer will also be charged the cost of deporting the laborer. These regulations are an attempt to deter employers from employing illegal labor, while also dispersing the responsibility of migrant control.

While the General Migration Law appears to be a way to organize and maintain a tight control over migrant laborers the law is unrealistic for many of the reasons outlined above. The law is not in line with the reality either the supply or demand side of migrant labors as the contract system presents prohibitive barriers to implementation.

\section{Summary}

The passage and application of the General Migration Law and its Regulation have not been effective; various aspects of the immigration policy are not coherent with the reality of the social and economic reality of the Dominican Republic. The reality of the Haitian immigrant situation at the time of the passage of the General Migration Law was that the Dominican economy required Haitian workers and the majority of them were undocumented, meaning there was a strong need for a regularization plan (CEFASA/CEFINOSA 2012:72). Article 151 of the General Migration law outlined a 
regularization plan that would work to give regular status to Haitians and Dominicans of Haitian descent that have proven their settlement in the DR.

The General Migration 284-04 and its Regulations for Procedure 631-11 laid out a comprehensive plan for both the regulation and enforcement of immigration, yet the majority of this law has not been enforced or put into action. Part of the reason for this is the fact that the law created a number of institutions such as the National Council of Migration, the National Institute of Migration, the Office of Labor and several administrative offices; yet these institutions still do not exist. These institutions are referenced in several of the articles and form part of the critical infrastructure for the implementation of the law. The lack of the development of the necessary infrastructure; the lack of enforcement or implementation of the law; and the lack of feasibility given the realistic immigration situation in the Dominican Republic have left many believing that the law is merely a formality (CEFASA/CEFINOSA 2012:54)

One of the things that this law does effectively do is create the framework for migrant illegality and deportability. Within the law several articles spell out the condition for migrant illegality and they are repeated in the law several times. One of the concerns of this is that the law also deems immigrant "illegal" rather than state that these individuals acquire illegal juridical status. This is important given the already social and racially charged relationship between the Dominican state and Haitian immigrants.

Not only does the law establish and outline migrant illegality, but it establishes mechanisms through which this illegality can be monitored and policed. The burden of immigration control is dispersed in this law to medical centers, employers, and those who work in public transportation. These all become sites of illegal migrant searches. 
The law does not provide a realistic way for long-term residing Haitians to regularize their status. Applying for permanent residence is unobtainable for most Haitians given the requirements of profession, income, or educational level requirements of the law, but the application process itself is prohibitive. In a survey taken in 2011 by the Jesuit advocacy group Centro Bonó, $76 \%$ of their clients cited high cost as the reason they were unable to regularize their status. The lack of work visas that reflect the actual reality of the economic situation in the Dominican Republic means that these individuals, despite residing in the country for decades, will remain undocumented unless the regularization program changes that.

The most significant changes the law created is that it created a group of nonresidents and then stated that all non-residents should be considered in-transit, therefore ending birth-right citizenship according to article 11 of the Dominican Constitution. This will make it impossible for the children of undocumented Dominicans of Haitian descent or Haitians to ever enjoy Dominican nationality "regardless of the fact that many of these individuals, their parents and grandparents have lived in the country for decades, this exception is being used extensively to deny documents to Dominican-born Haitians" (Kosinski 2009:390). This new change is also being used as the stipulation to retroactively strip Dominican born children of Haitian descent nationality through the new Constitutional Court Sentence.

\section{Analysis of the Legislative Build-up to Sentence 0168-13}

Before the passage of the 2004 General Migration Law there was both a social and legal build-up to the development of the law as well as the further development of the subsequent laws. As immigration began to diversify and increase with the "new 
migration" beginning in the 1980's Haitians became more visible and mobile within Dominican society. Haitians, who had either been residing in the Dominican Republic long-term and newer immigrants encountered administrative resistance when attempting to document their children born within the Dominican Territory. The resistance and discrimination eventually became legalized and this debate has led us to Sentence 016813.

While an analysis of each of the laws or legislative activity that led up to this point is not analyzed in-depth, this section aims to provide the necessary context for Sentence $0168-13$ as well as contribute to the narrative this research is attempting to produce.

\section{Jus Soli Citizenship}

From 1929 through January 26, 2010 the children of Haitians, despite their immigration status, were eligible to document their children as Dominican citizens under the article 11 of the Dominican Constitution, which granted all individuals born in the Dominican Republic jus soli citizenship. The principal of jus soli is citizenship granted based on the location of a person of birth, "birthright citizenship", in contrast to jus sanguinis citizenship determined on the basis of blood relationships or ancestors (Bolemaradd, Korteweg, and Yurdakul 2008: 158). The exception to this rule were the children born to those "in-transit", which at time of the clause's inception in 1939, intransit was officially defined as diplomats and those who would be passing through the country for less than ten days (Wooding and Moseley-Williams 2004, Bartlett, Jayaram, and Bonhomme 2011). 
Despite the constitutional definitions, the use of the "in-transit" clause to discriminatorily deny birth registry to Dominicans of Haitian descent is well documents (Baluarte 2006; Kosinski 2009; Wooding and Moseley-Williams 2004). On its face the "in-transit" clause appears to address short term visitors; yet it was broadly and arbitrarily interpreted to encompass foreign nationals, mainly Haitians, residing in the country (Wooding 2008). Citizenship in the Dominican Republic is defined at the constitutional level, but it is managed by the municipal offices of the Junta Central Electoral (JCE), the Central Electoral Board or Civil Registry. The JCE is the government office charged with organizing elections and controlling citizenship through the issuance of identity documentation such as birth certificates and the Dominican cédula, the main form of identification in the Dominican Republic (Wooding 2008).

The civil registry officials at the JCE are the guarantors of citizenship, as the officials are the ones who determine who is eligible for Dominican citizenship. The inconsistencies and arbitrary interpretations of the application of the in-transit clause across different civil registries around the country have historically confounded the ability of Dominicans of Haitian descent to receive documentation (Open Society for Justice 2010). The JCE was reported to deny birth certificates to children of Haitians, liberally applying the "in-transit" clause and basing judgments on Haitian sounding names, skin color, or accented Spanish (Martin, Midgley, and Teitelbaum 2002).

Birth registration means the conferral of nationality and citizenship in the Dominican Republic, therefore the denial of a birth certificate effectively leaves the child without citizenship and an identity. A cedula or a birth certificate are required for opening a bank account, obtaining employment, receiving a public education beyond the 
eighth grade, attending university, signing a contract, voting, access to social benefits, medical insurance, to get married, or to travel the country free from harassment or deportation.

The children of Haitian immigrants have been systematically blocked by the broad and liberal interpretation of the "in-transit" clause at the civil registry offices, with no clear process of appeal with denial (Wooding 2008). The negation of birth certificates leaves Haitians and Dominicans of Haitian descent without access to a juridical personhood and renders them stateless, making them vulnerable to expulsion from the country (Baluarte 2006).

Yean and Bosico vs. the Dominican Republic

While statelessness is not an issue unique to the Dominican Republic, The Dominican Republic has stood out as an exception to the trend in the Americas of adherence to Jus Soli citizenship policies, largely mitigating the situation of statelessness (Kosinski 2009).The historic discriminatory rejection of citizenship of Dominicans of Haitian descent drew the attention of many pro-migrant entities and organizations who sought a strategic plan focused on piecemeal legislation reform in the DR (Wooding 2008). In October of 1998, MUDHA, the Center for Justice and International Law (CEJIL), and the International Human Rights Law Clinic at the University of California Berkley petitioned the International-American Humans Rights Commission on Human Rights on behalf of two young girls, Dilicia Yean and Violeta Bosico, who were denied birth certificates despite the fact that both of their mothers had Dominican citizenship and proof that both girls were born in the Dominican Republic. 
The claim was that both girls were denied Dominican nationality on the basis of their Haitian descent, therefore alleging violations of the American Convention on Human Rights by the Dominican government (Baluarte 2006). In an attempt to avoid litigation before the Inter-American Court, the Dominican government issued birth certificates to Yean and Bosico in 2001; despite this effort the victims and their representatives requested that the Inter-American Human Rights Commission take the case before Inter-American Human Rights Court (IAHRC) (Baluarte 2006). In September of 2005, the Inter-American Court handed down its landmark ruling:

"The Inter- American Court found that the Dominican Republic had violated the girls' rights to nationality, equality before the law, a juridical personality, a name, and special protections as children, in conjunction with the state's obligation to respect the rights guaranteed in the American Convention" (Baluarte 2006:27).

The Court considered the Dominican Constitutional doctrine of jus soli and made it legally binding for the Dominican state to comply with its Constitution (Wooding 2008). In addition the Court determined that the "in-transit" clause could not be interpreted so broadly to include all undocumented migrants (Baluarte 2006). The IAHRC ruling was "the first time that an international human rights tribunal has unequivocally upheld the international prohibition on racial discrimination in access to nationality" (Open Society Justice Initiative 2005). The IAHRC's decision was anticipated to have great impacts on the development of legal norms concerning discrimination and nationality, not only in the Dominican Republic but internationally; yet the Dominican Republic's reaction and subsequent actions in response to the case have eliminated hopes of potential benefits toward combating discrimination.

The case of Yean and Bosico became exemplary, but represented the thousands of Dominicans of Haitian descent who were relegated to statelessness in a blatant breach of 
the Dominican constitution (Kosinski 2009:385). The ruling exposed the discriminatory practices of the Dominican state on an international level, confirming institutional discrimination of Dominicans of Haitian descent and then ordered the state to develop measures to rectify these practices (Wooding 2008).

According to David Baluarte (2006), an attorney for the Center for Justice and International Law (CEJIL), "this decision has thrust Dominican society into a furious debate, and although the outcome of that debate is still unclear, a number of implications are quickly coming to light" (p.25).As we are now approaching seven years since the landmark 2005 Yean and Bosico ruling, the implications of the ruling have continued to "come to light" and develop into what has now institutionalized the state's discriminatory stance toward Haitians and Dominicans of Haitians descent.

The Dominican Republic has refused to comply with the majority of the InterAmerican Human Rights Court's decisions, and has in fact begun to establish legal framework to make it close to impossible for Dominicans of Haitian descent to obtain citizenship. Part of this framework was the broadening of the in-transit definition to include all non-residents and foreigners with illegal status in number 10 of article 36 in the 2004 General Migration Law, explained in the analysis of the law.

\section{Resolution 12-07 and Circular 017}

The Yean and Bosico case may have motivated the development of the 2004 General Migration Law and the expanded interpretation of the in-transit clause. The Dominican Government's migration reform would not be stopped at addressing precluding nationality issues, with the help of two internal memorandums, the state began to develop framework to retroactively apply the new parameters of nationality, 
potentially rendering stateless a new population of Dominican citizens. In March of 2007, Circular 017 was issued to the all Central Electoral Board offices, this was a directive that instructed all Central Electoral Board offices to stop all action on birth certificates that had been issued "irregularly" to children of foreigners who had not proven their legal status in the Dominican Republic at the time of declaration (Teff and Margerin 2008).

Under this directive the civil registry officials were not to expedite, process, sign, or issue copies of identity documents when the applicants were possibly children of foreign parents, regardless of whether these individuals were born before the application of the 2004 migration law or were already in possession of identity documentation (Open Society for Justice 2010). The Circular did not stipulate under what criteria "irregularity" would be determined, nor defined a time frame for the investigation (Kosinski 2009).

In the same year of the Dominican state also passed Resolucion 12-2007 (Resolution 12-07) which works in conjunction with the Circular 017. This resolution authorizes the provisional suspension of "irregular" documents, including birth certificates, and the Dominican cédula, the Dominican identity card pending an investigation of these documents (Open Society for Justice 2009). The objective of Circular 017 was to impede access to certified copies of birth certificates or renewal of cédulas for Dominicans of Haitian descent; whereas the objective of Resolution 12-2007 was to actually suspend the documentation of the bearer pending an investigation Open Society for Justice 2009).

These two administrative documents worked in conjunction with the General Migration Law to block access to identity documentation and suspend the citizenship of Dominicans of Haitian descent for an undefined period of time. The assumed purpose 
was to then investigate the documents of individuals thought to have been born to Haitian parents in order to retroactively apply the new definition of in-transit defined in the 2004 immigration laws therefore rendering these individuals ineligible for citizenship.

\section{Constitution Change}

The nail in the coffin for any hopes of the Dominican state revising its immigration policies to be more in-line with international standards came with the revision of the Dominican Constitution on January 26, 2010. At the time of passage, the General Migration Law 285-04, and both the Circular 017 and Resolution 12 worked in contrast to the Dominican Constitutional policy on citizenship.

In the newly revised constitution Article 18 made the language of the General Migration Law of 2004 constitutional, changing the "in-transit" clause to include nonresidents, migrant workers, and those who had overstayed their visas (Opens Society Foundation 2010). The constitutional change has made the determination of nationality of Dominicans of Haitian descent completely dependent on the nationality or documentation status of their parents.

This constitutional change has now made it close to impossible for those born after 2004 to parents lacking "acceptable documentation” to become citizens. This has rendered these children stateless, and therefore constantly vulnerable to deportation and unable to incorporate into formal Dominican society (Bartlett, Jayaram, and Bonhomme 2011:588). Dominicans of Haitian descent born before 2004, who have possessed documentation all of their lives and have conducted their lives as Dominican nationals have not dodged any bullets, Circular 017and Resolución 12 were relegated thousands of Dominicans of Haitian descent to citizenship limbo. 


\section{Analysis of Constitutional Court Sentence 0168-13}

Since the passage of Resolution 12-07 and Circular 017, in 2007 there have been many individuals and human rights organizations that have taken cases of suspended identity to local courts. The implementation of Resolution 12-07 called for the temporary suspension and investigation of identity documents, but there was no explanation for this investigation or explanation regarding how long the investigation would take. The individuals affected by the Resolution 12-07 understood that they temporarily lost their civil status and ability to participate in formal society. They no longer had the ability to legally work, travel, and enroll in university or high school, until the State decided to reinstate their documentation or. The passage of Sentence 0168-13 represents the first response that these individuals have received from the State since the passage of the Resolution five years ago, and it has been devastating.

The Sentence was passed by the Constitutional Court in response to a court case presented by Juliana Dequis Pierre in June of 2012. The basis of the case stated that the Central Electoral Board in the province of Monte Plata had refused to grant Ms. Pierre a Dominican cedula, the national identification card and refused to issue her an official copy of her birth certificate. The Central Electoral Board denied Ms. Pierre identity documentation on the basis that her parents were foreigners and in accordance with the constitution she was ineligible for citizenship; despite the fact that she has enjoyed citizenship since she was born in 1984.

Sentence 0168-13 is structured as a deliberation of the case of Juliana Dequis Pierre, as well as an elaboration of the Constitutional Court's interpretation of the Dominican Constitution and immigration laws. Through this process the Sentence 
discusses the definition of citizenship and nationality in the Dominican Republic, establishing the State's position in regards to the issue of citizenship for Haitian descendants.

This analysis will be structured differently from the previous analyses, due to the different structure and nature of this document. I will include sections of the document that have been analyzed, all translations are my own.

Nation- State Sovereignty

The Sentence states many times throughout the document that the question of the determination of nationality is at the discretion of sovereign nation- states. According to the Sentence the conservation, safeguarding, and correction of nationality is the sole function of the state:

Que la nacionalidad es un aspecto de la soberanía nacional, discrecional de los Estados, la cual es concebida como un atributo otorgado por estos a sus nacionales y cuyo alcance, por tanto, no puede ser definido por la voluntad de un juez ordinario. (p. 7)

Nationality is an aspect of the discretionary national sovereignty of states, which is conceived as an attribute given by their nationals and whose scope, therefore, cannot be defined by the will of an ordinary judge

La nacionalidad es una cuestión de orden público que corresponde al Registro Civil de cada país su conservación, corrección y salvaguarda, otorgando la legislación de la Republica Dominicana dichas funciones (p.12)

Nationality is a matter of public order whose conservation, correction, and safeguarding corresponds to the civil registry of each country granting the legislation of the Dominican Republic these functions

Throughout the entire document there are statements in regard to the State's responsibility and right to determine and safe-guard Dominican nationality, including a 
section in which the sentence discusses international definitions and agreements in

regards to the determination of citizenship.

En el Derecho International Publico, desde casi un siglo, la configuración de las condiciones para el otorgamiento de la nacionalidad ha sido internacionalmente reconocida como parte del dominio reservado a competencia nacional exclusiva del Estado (p. 25)

In the Public International Law, for nearly a century, the configuration of the conditions for the granting of nationality has been internationally recognized as part of the domain reserved to exclusive national competence of the State

The Sentence makes it clear that it is not only a right but an obligation for the state to determine citizenship, but an obligation of sovereign nation-states to protect their nationality from those that would violate it. The tone throughout the Sentence implies that Dominican citizenship is under attack and must be rescued from those who chose to defile it:

Que la recurrida reitera su compromiso de cumplir y hacer cumplir el mandato de la constitución y las leyes, a la vez de que de garantía de que la identidad nacional será reguardada y preservada celosamente por esta institución, y que estamos aplicando un programa de rescate y adecentamiento del Registro del Estado Civil a fin de blindarlo de las acciones fraudulentas y doloras, falsificaciones y suplantaciones que por tanto tiempo han afectado el sistema de Registro Civil dominicano, de tal manera que podemos brindar a la ciudadanía un servicio eficiente y seguro respecto de los actos vitales que son el soporte y la base de la identidad nacional (p. 9)

The contested reiterates its commitment to comply with and to enforce the mandate of the Constitution and the laws, both of which guarantee that national identity will be protected and jealously preserved by this institution, and that we are applying a rescue and ordering of the civil status registration program in order to shield the fraudulent actions and painful forgeries and impersonations that for so long have affected the system of Dominican Civil Registry, in such a way that we can provide an efficient and safe service in the vital acts which are based on national identity and the support to citizenship 
In order for the state to protect the status of nationality the Sentence states that the law then gives the corresponding institutions the right and responsibility to purge or purify the civil records in order to clean its national electoral registry. These actions of purging and cleaning out the civil registries began in 2007 with the investigations of Resolution 12

Que la Ley faculta a la Junta Central electoral a tomar todas las previsiones tendentes al control y depuración de las solicitudes de documento de identidad, a los fines de fortalecer el proceso de depuración del registro Electoral (p. 8)

The law empowers the Central Electoral Board to take all measures aimed at the control and purging of applications for identity documentation, for the purpose of strengthening the process of purification of the voter registry

The irregularities that will need to be purged are not only those that refer to administrative errors. In the Sentence, nationality and citizenship are defined not only as both legal and political ties to the State, but a sociological link, that implies creating a society with the desired ethnic and racial traits:

De manera general la nacionalidad se considera como un lazo jurídico y político que une a una persona a un Estado; pero, de manera más técnica y precisa, no es solo un vínculo jurídico, sino también sociológico y político, cuyas condiciones son definidas y establecidas por el propio Estado. Se trata de un vinculo jurídico, porque de él se desprenden múltiples derechos y obligaciones de naturaleza civil; sociológico, porque entraña la existencia de un conjunto de rasgos históricos, lingüísticos, raciales y geopolíticos, entre otros, que conforman y sustentan una idiosincrasia particular y aspiraciones colectivas; y político, porque esencialmente, da acceso a las potestades inherentes a la ciudadanía, o sea, la posibilidad de elegir o ser elegido para ejercer cargos públicos en el Gobierno del Estado (p. 24)

In general nationality is considered a legal and political tie that binds a person to a State; but, in more technical and precise way, it is not only a legal link, but also sociological and political, whose conditions are defined and established by the State itself. It is a legal link because of the relationship of many rights and obligations of a civil nature; sociological, because it implies the existence of a set 
of traits, historical, linguistic, racial and geopolitical, among others, that conform and sustain particular idiosyncrasies and collective aspirations; and politically, because it essentially gives access to the powers inherent in citizenship, i.e. the possibility to choose, or be elected to public office in the Government

Here the State appears to be saying that it has the right to decide on who is allowed citizenship and into the collective national identity based on sociological traits that it finds desirable. The Sentence upholds that the State's decision to review the records is not a discriminatory act, but rather the state need to begin with birth certificates as they are the basis of all other identity documentation. Because this revision of the records is only going to affect Haitian immigrants we are inclined to assume that this in fact may be a discriminatory act. While the Constitutional Court is ordering the review of the records it acknowledges that it may leave many individuals stateless, but then refers them to the Haitian embassy to secure nationality.

\section{Haitian Invasion?}

The Sentence begins to build the case that the Dominican State has always been clear about who constitutes Dominican citizens, seeming to distinguish mainly from their Haitian neighbors.

Desde el 1844, el constituyente ha establecido quienes eran dominicanos, principio este que se ha mantenido desde la reforma de mil novecientos noventa y nueve sin alteración alguna hasta el día de hoy (p. 7)

Since 1844, the constituent assembly has established who Dominicans are, a principle that has been maintained since the reform of 1929 without alteration to the present day

This statement is interesting because 1844 is the year that the Dominican Republic received its independence from Haiti. Therefore by stating that in 1844, the Dominican state determined who was Dominican and who was not appears to imply a reference to Haitians. The date of 1929 is also significant, as it was the year that the 
Dominican Republic and Haiti created the first official border during the US occupation of Haiti

Basis for the Rejection of Nationality

The basis for the stripping of citizenship is related to the interpretation of the intransit clause of the constitution before the 2010 Constitutional change. The Sentence states that the constitution of 1929 stated that "not all who are born in the territory of the Dominican Republic are born Dominicans" (Sentence 0168-13:7). The Sentence clarifies that an individual is not born Dominican if they are the child of a foreign mother who at the time of giving birth is in an irregular situation and cannot justify her entry or residence pg. 8 .

In addition to stating that these individuals were never entitled to citizenship, it uses language that criminalizes individuals who were able to obtain documentation through all of the proper channels:

Que los padres de la recurrente son extranjeros que de manera ilícita e irregular han inscrito a sus hijos en los libros de Registro del estado civil, en franca violación de la constitución vigente al momento de la declaración (pg. 7)

The parents of the appellant are foreign in an unlawful and irregular way have registered their children in the registry of civil status, in blatant violation of the constitution current at the time of the declaration

The sentence states that it is criminal for anyone to possess documents that they should not. This deflects all responsibility from the General Electoral Offices that administered these documents, as well as the general interpretation of the law before the 2004 law.

While the rhetoric in the press and everywhere else has been that the state is retroactively stripping citizenship, in this sentence we have an opportunity to view the 
perspective of the state. According the language in the Sentence, it is purging its records of the fraudulent and illegally acquired documents and thereby protecting the Dominican national identity. 


\section{CHAPTER VI \\ DISCUSSION, CONCLUSION AND RECOMMENDATIONS}

\section{$\underline{\text { Discussion }}$}

This research began with the assertion that the Dominican state has worked to create a large population of illegal and deportable immigrants for two main reasons. The Dominican government has used immigration policy to assert its territorial sovereignty to emphasize the historically embedded ideology of antihaitianismo. Secondly, the Dominican state has used immigration policy and its selective enforcement to maintain a large vulnerable Haitian workforce.

In order to address these assertions, this paper has presented analyses of different components of the relationship between the Dominican state and Haitian immigrants, ending with the legal construction of Haitian migrant illegality and thus their deportability in Dominican immigration laws. I would like to continue to address these assertions by using the theoretical framework as a lens through which we can interpret the information presented.

\section{Cornelisse and DeGenova}

The theoretical framework was developed using the works of both Galina Cornelisse and Nicholas DeGenova. Both of these authors look at the phenomena of undocumented immigration, yet they focus on different perspectives. Cornelisse focuses 
on how rights are dependent on the territorial nation-state system, while DeGenova's focuses on how "illegal" populations are functional to the capitalist state. The Dominican government presents itself in Sentence 0168-13 as a sovereign state that has the right to determine the basis for citizenship and the development of immigration policy. Cornelisse's analysis of the nation-state system allows for a better understanding of how the Dominican state has been able to retroactively strip citizenship from these individuals within this logic, and what this means in terms of rights for these individuals. Cornelisse's work provides tools to understand the how: how is the Dominican Republic able to pass legislation that would leave thousands of individuals stateless? How are these individuals are made vulnerable and exploitable by their lack of territorial membership?

The work of DeGenova provides analytical tools for understanding the motives of the state, the why: why would the state choose such drastic measures? Who does this benefit? DeGenova's work becomes useful in interpreting the actions of the state, and placing them within a larger context of "illegal" populations around the world. Although they may be approaching the topic from different angles, both of these authors are instrumental in understanding different perspectives of this complex problem.

\section{Dominican Nation-State Sovereignty}

The work of Cornelisse breaks down the territorial nation-state system, which provides insight into how rights are connected to territory. For Cornelisse, the modern state system based on territoriality appears to be sacred and untouched, which allows for the international and national justification of deportation of those that present a "threat" to national sovereignty (Cornelisse 2010). Within the specific context of Haitian immigrants in the Dominican Republic, the work of Cornelisse is useful in the 
development of understanding how the Dominican state has been able to use sovereignty as the reasons for why it is allowed to continually chip away at the civil rights of Haitians and their descendants.

According to Cornelisse the global organized system of territorial nation-states is one in which rights are connected to the state. The state is the sole arbiter in determining who deserves rights and who does not. This system means that individuals who are not connected the state can fall into a space of rightlessness; it is within this space of rightlessness that an individual's labor power can become exploited and vulnerable.

According to the logic of territoriality and the modern nation-state system, the Dominican Republic, as a sovereign nation, has the obligation to decide who does or does not belong within their territory; even if this means individuals who once enjoyed the right and privilege of citizenship. Throughout the Sentence the Constitutional Court has established the firm position that the determination of Dominican nationality is a matter that is solely for the sovereign nation-state, and that the Constitutional Court has stated that it is the objective of the institution to jealously guard nationality against those who would defile it.

This Dominican state has used its so-called sovereign power to inflict the violence of retroactive stripping of citizenship, deportation and detention on the Haitian population and their Dominican born descendants. This action pushes these individuals into a space where they are rightless and excluded from personhood within the state, yet these individuals are included through their labor power. The Dominican Republic has created a deportable populations based on territoriality, and then has pushed this population to continue to be used as a vulnerable labor commodity. 
These observations of the immigration policy follow DeGenova's observation that illegal populations are not random and self-creating, nor is "illegality" a characteristic of particular individuals (2002). The Dominican state has basically created the infrastructure for illegality through the immigration law to ensure that Haitians will not have easy access to legal residence, and their offspring will inherit their irregular status. The state lays the basic infrastructure for illegality, and then selectively chooses to enforce or enact the policy, encouraging migrant illegality but keeping it under control through the threat of immigration law enforcement.

Based on the territorial system of state sovereignty the Dominican state is within its power to create an infrastructure that discriminates and creates two classes of individuals within the territory. They can assert their power and flex their sovereign muscles to decide to retroactively apply its policies or declare an entire class of people a threat to the territory. These individuals are then pushed into a space where they are void of rights; if they have lived all their lives in the Dominican Republic they have no connection to rights in Haiti, while they do not have rights in the Dominican Republic.

\section{Denaturalizing Haitian Migrant Illegality}

According to DeGenova, migrant 'illegality' tends to considered immutable and unquestionable, as if it were an abstract "matter of fact" concept that existed without the law, this is what DeGenova calls the fetishization of migrant illegality (2013: 1182). Through an in-depth analysis of the immigration policy we were able to see that not only the literal construction of migrant illegal in the laws, but analyze the ways in which the law could create situations of migrant illegality for Haitians. Apart from the literal distinction of who can be considered illegal, the Dominican state created migrant 
illegality through the following ways: a lack of a comprehensive immigration policy and enforcement, the adherence to an outdated and out of touch immigration policy, and the selective use of immigration policy enforcement.

Beginning with the 1929 immigration law, the immigration category under which the large majority of Haitians would qualify was the category of non-immigrant, in the sub-category of temporary laborer. While this criteria of entry for Haitians may have fit the social and economic reality at the time of its implementation, the "new migration" changed the landscape for Haitians as they entered the territory to meet the growing need for labor.

During the 69 year gap between the passage of the Law of 1939 and the General Migration Law of 2004, the state did not make legislative changes to reflect the changing economy and reality of the Haitian presence. This means that between 1939 and 2004 close to 500,000 Haitian immigrants have come to reside within the Dominican territory without any feasible way to legalize their status due to the absence of a realistic or functioning immigration option for this group.

The States adherence to the subcategory of temporary laborer has ironically pushed more immigrants toward irregular status than it has regulated. The Dominican state has effectively created the situation where the large majority of Haitian migrant workers are undocumented.

\section{The Border Spectacle}

It is difficult to believe that the Dominican state was completely unaware of the immigration situation or was unable to develop more effective immigration policies for 69 years while half a million Haitian migrant workers entered and exited the Dominican 
territory at any time, and produced more than 200,000 descendants. Why has the state decide to turn a blind eye to irregular immigration yet periodically develop drastic legislation to restrict or discipline this movement? My assertion is that it is a mechanism to control Haitian laborers, which I explain using DeGenova's concept of the Border Spectacle and the obscenity of inclusion.

According to DeGenova migrant illegality is activated through the performative act of immigration law enforcement. The Border Spectacle is the way in which the law that produces migrant "illegality" continues to maintain its elusiveness and migrant "illegality" is naturalized. In order for this to happen "illegality" must be activated, and the Border provides the theater for spectacle of producing the "illegal alien" (DeGenova 2002:436). While illegality is a function of the law the Border Spectacle is what provides the scene of exclusion, where illegality has putative becomes reified and enacted through enforcement(DeGenova 2013:1181).

Migrant "illegality" and the Border Spectacle discipline immigrants through the constant threat of deportation, migrant deportability qualifies their labor making undocumented workers a disposable cheap commodity. According to DeGenova the Border Spectacle and the fetishization of the supposed transgression of "illegal" immigration hides the publically unacknowledged secret of the sustained recruitment of undocumented labor, this is what DeGenova calls the 'dirty secret' or the "obscene of inclusion" (DeGenova 2013: 1185).

The Border Spectacle works as a paradox; the Border Spectacle constructs the borders as spaces of policing and exclusion, yet they are also sites of recruitment and inclusion (DeGenova 2013: 1189). The inclusion of migrants comes in the utility and 
demand for their cheapened labor power, but also as a legal construction and fetishization of the "illegal," devious, and law-breaking non-citizen that is juxtaposed with the full-rights bearing citizen.

According to DeGenova, "What is at stake, then, is a larger sociopolitical (and legal) process of inclusion through exclusion, labor importation (whether overt or covert) premised upon protracted deportability" (DeGenova 2013:1184). The Border Spectacle directs attention to the sight of the "transgression" of unauthorized border crossing naturalizing the "illegal" state, and dramatically employing material means of detecting, deporting, and apprehending the undocumented, while the inclusion of immigrants as a workforce is banal and downplayed. Immigrant inclusion is the obscene supplement of the Border Spectacle and is sustained.

DeGenova is saying that the Border Spectacle is an ideological edifice, that supports immigration law, which works to not only normalize illegality and exclusion, but also the inclusion of migrant labor as well (DeGenova 2013: 1189). This is extremely relevant to the Dominican state and immigration law. The Border Spectacle in the Dominican Republic has involved the development of legislation that is ineffective and unrealistic, combined with the selective implementation which has forced individuals to maintain an undocumented status.

Through the immigration reform attention has been drawn to the "illegality" of Haitians and their descendants, as well as their "fraudulent" acquisition of citizenship, while completely downplaying the economies growing dependence on their labor. These actions obscure from the public the mass recruitment and use of Haitian labor within the 
Dominican economy, while emphasizing the need to protect the territory from the Haitian threat.

\section{Citizenship and Ideological Borders}

The dominant argument regarding citizenship and immigration in the Dominican Republic centers on the long contentious history between the two countries and the development of dominant ideologies which promote racist and discriminatory views of Haitians. Dominicans may distinguish themselves from Haitians through citizenship, but the relationship of distinction and reproduction of Dominican society has a political and ideological dimension, where Haitian culture and immigration has been portrayed as antagonistic and detrimental to Dominican society. This discursive formation of Haitians as infectious and detrimental to Dominican society is made worse as the immigration reform continues to illegalize their status.

The Border Spectacle emphasizes transgression, which is combined with the already existing antihaitianismo to inspire fear and loathing towards Haitian immigrants and construct them as non-citizens. These feelings can supply the rational for the enforcement of the Border Spectacle, even if the measure is as dramatic and bizarre as retroactively stripping citizenship from Haitian descents dating back 84 years. The combination of illegality, the Border Spectacle, and antihaitianismo taken as the full ideological package enhances the need for the exclusion of the threatening Haitian other.

Citizenship is a legal status, but citizen-making also involves strategic decisions that are made about who is to be included, what kind of access to resources they have, and how collective national identity is formed and maintained (Isin and Turner 2007:14). 
Citizenships counterpart, the non-citizen is therefore void of rights and the ability to make clams of the state.

Discursive formations that work to emphasize the differences between citizens and non-citizens can be formed by text, subtext, rhetoric, or accusations and work in the Border Spectacle to generate a naturalized image of exclusion for "illegal" immigrants (DeGenova 2013:1181). The cultural meanings attached to "illegal" status also play a role in contributing to migrant vulnerable as their lack of citizenship devalues their labor and legitimizes their exploitation (Bauder 2008:320). Non- citizens are denied access to a shared identity, and a sense of belonging in societies where they contribute economically; they may also be denied labor protections, civil and economic rights that citizens receive (Bauder 2008:326).

The combination of legal status, cultural and social positioning within society renders "illegality" as an intrinsic deficiency of migrants themselves, who might then be characterized as undeserving of citizenship (DeGenova 2013: 1191). The castigation, denunciation, and deportability of migrants supply the rational that there are essential differences between citizens and non-citizens that can then be racialized (DeGenova 2013:1180).

These ideas are what have contributed to the ideological justification for the retroactive stripping of citizenship from Dominicans of Haitian descent. The Sentence 0168-13 is a Border Spectacle and works not in the sense to activate illegality, but to activate antihaitianismo ideology, where it may not have existed before. The Sentence reinvigorates the idea that Haitians who are non-citizens are fundamentally different from Dominicans; these individuals have deceptive intentions of Haitianizing the country and 
should be seen as threat. The Border Spectacle of retroactive stripping allows the Dominican state to demonstrate its vigor and nation-state authority in the face of this "threat" through an "emphatic and grandiose gesture of exclusion" (DeGenova 2013:1181).

\section{Conclusions}

As the analysis of the legal framework of immigration in the Dominican Republic demonstrates, the Dominican Republic has had a lack of comprehensive immigration policies since the 1980s. This has specifically affected Haitians and their descendants, as the demand for their labor continued to increase, the development of a legitimate form of regularization has not followed.

After almost 30 years of unregulated and unenforced immigration laws, Sentence 0168-13 represents a dramatic and most drastic form of immigration reform. The question that has remained unanswered, is why? Why has the Dominican state chosen such drastic measures and why now? While empirical research will need to be conducted in order to fully address this question, below I would like to explore some of the theories and ideas that have emerged that attempt to explain why the state has decided to pass this Sentence now.

\section{Increasing Awareness of the Haitian Population?}

Follow the development of the legal struggles regarding citizenship for Haitians and especially for their descendants a progression of legal activity has developed, which leads into a possible explanation on why the state has decided to conduct a reform on immigration policies: there are simply more Haitians in the Dominican Republic and their 
attempts to gain citizenship by any means needs to be thwarted. Evidence for this theory can be seen in a section in the Sentence which outlines the argument of the State:

En la Republica Dominicana existe una gran cantidad de extranjeros que aspiran a obtener la nacionalidad dominicana, cuya mayor parte son indocumentados de nacionalidad haitiana (pg.22)

In the Dominican Republic there is a large number of foreigners who aspire to obtain Dominican Nationality, most of which are Haitian Nationals.

The Sentence then goes on to discuss the results of the First National Survey of Immigrants, stating that $7 \%$ of the immigrant population is now comprised of Haitians and their descendants; of which the Dominican government has a record of only .16\% (pg. 23). It appears in this passage as thought the State is expressing that the number of Haitians and their descendants in the Dominican Republic comes as a shock and that action must be taken to control or at least document the population.

This new awareness of the reality of the Haitian population and the fact that their offspring were obtaining Dominican citizenship may have begun in the 1980s and continued to build until the current Sentence. As presented earlier in the document, the 1980s brought what is called the new migration, this meant that Haitians were beginning to branch out into different economic sectors and became more mobile within Dominican society. Around the same time many Haitians and Dominicans of Haitian descent were finding persistent systematic discrimination when attempting to document their children. The discrepancy in the granting of citizenship came in the arbitrary and inconsistent interpretation of the in-transit clause in the Constitution.

This problem of how to interpret the Constitutional definition of citizenship was brought to international attention by the Inter-American Human Rights Court in the case of Yean and Bosico vs the Dominican Republic. The Inter-American Human Rights 
Court ordered the Dominican Republic must stop the discriminatory refusal of citizenship. This court case may have been the beginning of the State beginning to gain awareness of the fact that the descendants of Haitians were acquiring citizenship through an un-unified interpretation of the Constitutional definition of jus soli citizenship

It was after this ruling that that Dominican state began to reform its immigration policies, beginning with the 2004 General Migration Law which clarified the in-transit definition. Following the implementation of the immigration law came the creation of Resolution 12-07 and Circular 017, which we know now were intended to investigate how many Haitian descendants were able to document their children and successfully become citizens.

These investigation, combined with the results of the First National Survey of Immigrants in the Dominican Republic, informed the state of the large number of Dominican born Haitians in country who had obtained legal citizenship. The 2010 Haitian Earthquake may have also contributed to the feeling of urgency on the part of the State, as the disaster increased Haitian immigration to the Dominican Republic by $20 \%$. These factors may have motivated the creation and implementation of Sentence 0168-13, in order to purge the records of all irregularities.

This theory makes some sense, considering the documented evidence of the Dominican State's lack of organization and coherency regarding the interpretation of citizenship in the different registry offices. The historically embedded belief that Haitians have the desire to take over the island through a passive population invasion may contribute to why the State felt like it had to make a drastic change in the face of a growing Haitian immigrant population. 


\section{Useful Distraction?}

Another theory that might explain the dramatic Sentence is that the utility of Haitian illegality might extend beyond the economic benefits; the flames of antihaitianismo and illegality have historically been fanned when the Dominican government needs a convenient distraction.

The last year of 2013, was an active year for protests from teachers, doctors, and nurses as well as strikes demanding the completion of roads, bridges and other infrastructure projects (Chery 2013). Many people in the media have speculated that the state decided to take this action now to distract the public over taxes, high unemployment levels, and reports of government corruption and stealing (Garcia- Peña 2013).

Renowned Dominican- American author Junot Diaz is among the group that have publically denounced the Sentence as a means to distract from government thievery and corruption.

The use of antihaitianismo to distract the public is not a new theory.

Anthropologist Samuel Martinez (2003) argues that the tension between Dominicans and Haitians is not a result of the history between the two nations, but rather that the tensions have inflamed through the instrumental use of antihaitianismo sentiment by the Dominican state:

Since the ethnic cleansing of the Dominican frontier region in 1937, anti-Haitian campaigns have been repeatedly conjured by Dominican politicians as a diversionary tactic. While Trujillo may have played the Haitian card to divert his people's attention from the threat posed by U. S. neoimperialism, the Haitian immigrant today is more likely a scapegoat for the declining purchasing power of wages (p.94)

The political party in power now, the Dominican Liberation Party (PLD), has a history of using anti-Haitian campaigns for their own convenience. In 1996 the PLD 
staged a violent anti-Haitian campaign against the presidential candidate Jose Francisco Peña Gomez, who was born to Haitian parents. The campaign highlighted tenets of antiHaitian ideology and used Haitian stereotypes to discredit Peña Gomez as a legitimate candidate. This anti-Haitian campaign was repeated in 1997, as the PLD President Leonel Fernandez launched a deportation campaign to divert attention from growing social and economic needs of the country (Martinez 2003: 94).

Antihaitianismo is a powerful tool for the ruling class : "Anti-Haitian propaganda puts forward the Haitian immigrant as a scapegoat for problems in the Dominican political economy while state sponsored immigration from Haitian has created a mass of malleable nonunion labor" (Martinez 2003: 83). The new immigration laws seem to follow the same pattern of the anti-Haitian propaganda campaigns of the past. The Sentence draws attention to the Haitian problem, while obscuring the benefit of Haitian labor.

\section{Political Scheme?}

The research in this paper has primarily focused on the economic and sociocultural motivations of the Dominican state, yet there are other theories that believe that the Sentence may be part of an elaborate political scheme. Roger Noriega, former US ambassador to the Organization of American States, believes that the Sentence forms part of a plan to keep the ruling political party, the PLD, in power.

There are two major parties in the Dominican Republic: the Dominican Liberation Party PLD and the Dominican Revolutionary Party the PRD. The PLD has won the last four consecutive presidential elections, and represents an overwhelming majority in all areas of government. The PRD is the other major political party in the Dominican 
Republic. The PRD is the party of the late José Francisco Peña Gomez, a proud Dominican of Haitian descent, and one of the most popular Dominican leaders in history. Peña Gomez became one of the major pillars of the PRD, becoming the representative of the poor and black masses. Because of Gomez's association with the PRD, it is believed the party attracts voters of Haitian descent.

The current leader of the PLD is the former President of the country Leonel Fernandez. Fernandez has served three presidential terms, as he changed the Constitution in order to make more than two presidential terms possible. That was not the only change Fernandez made; during his last term of presidency 2008-2012 he created both the Constitutional Tribunal and the Electoral Tribunal. Both tribunals are made up of justices that have proven their loyalty to the PLD or have very close ties to Fernandez, including his former law partner and his sister-in-law (Noriega 2013).

Both the Constitutional and the Electoral Tribunals have been crucial in the development and the immigration reform that lead to Sentence 0168-13. It was also during Fernandez's Presidency that the 2010 Constitution change which stated that all undocumented foreigners would be considered in-transit, therefore permanently ending jus soli citizenship to individuals born to parents with irregular immigration status.

These Tribunals also play large roles in the electoral process, and have been accused of election fraud and rigging. In the 2012 Presidential election, current President Danilo Medina from the PLD won the presidency. Medina was Fernandez's chief of staff and personal confident; Fernandez's wife, Margarita Cedeño de Fernandez won the vice presidency. The outcome of the election led many to believe that Fernandez had a hand in the election and in keeping the PLD in power. Many believe that Fernandez is setting 
himself for a 2016 Presidential run. In December of 2013, media outlets had revealed that Medina and Fernandez have made a pact agreeing that Fernandez would run in 2016 and Medina in 2020 (Frontán 2013).

There are those that believe that Fernandez's ultimate goal is to create a one party state, this is the theory expressed in Carl Meacham's 2013 report to the Center for Strategic \& International Studies. According to the report there was a pact made between Fernandez and the PRD leaders which have split the PRD party in half. According to popular belief this pact was that the PLD would eventually usurp the PRD party. The PLD has become the stronger party, but faith in their ability to rule has eroded among claims of corruption, bribery, and money laundering (Meacham 2013).

While the political scheme becomes increasingly complicated the deeper one digs, the relation to Sentence $0168-13$ is that the PLD would like to weaken the voting power of the PRD through shrinking its voting demographic. Before the last presidential election in 2012 the PLD refused to give voter registration cards to individuals suspected to be of Haitian descent. Noriega (2013) believes that this is a hint that the Sentence may be connected to a political maneuver on the part of the PLD, as they have attempted to disqualify Dominicans of Haitian descent from voting.

\section{Limitations and Contributions of the Research}

\section{Limitations of the Research}

This study attempted to piece together the narrative of the legal production of migrant illegality in the Dominican Republic from the perspective of the legal documentation. Due to time, resources, and the scope of this project I chose to study some of the key pieces of legislation, yet apart from this legislation and the history I was 
able to present here there is still a fuller picture of the story that is not told here. A fuller picture of the immigration reform would attempt to include more sides to the story: the voice of the state, the economic stakeholders, and of those affected by the reform.

The time I spent in the Dominican Republic, and the vast amount of historical research and reading has given me great insight into the social, cultural, and historical background necessary to conduct this study. Despite this insight, the political history and complicated political workings of the Dominican state are still a mystery to me. A better understanding of the political process may have rendered information regarding how legislation is passed, who influenced the passage of the Sentence and the other pieces of legislation that led to this point.

Another limitation of the research is the timing of the analysis. The Constitutional Court Sentence 0168-13 was passed in September of 2013. The recent nature of the Sentence has meant that apart from media coverage, there have been no reports or investigations released regarding the Courts decisions, although they are undoubtedly in the works.

\section{Contributions of the Research}

This research has been conducted at a very timely period of time and will situate the shocking Constitutional Court Sentence passed in within a larger socio-historical and legal context. This research is a narrative that has attempted to piece the social, historical, and legal dimensions together to present a picture of immigration reform in the Dominican Republic. As the immigration issue continues to develop in the Dominican Republic work like the research presented here provides a basis for understanding; a springboard through which continued research may be developed. 
This research contributes to academic literature produced in English regarding the Haitian condition in the Dominican Republic. The existing literature is continuing to grow, but at the moment research conducted by non-profit, non-governmental organizations dominate the field.

Therefore this research aspires to contribute the sociological perspective of the Haitian presence in the Dominican Republic while including the economic and legal perspective to the long-standing racial arguments that dominate the literature. 


\section{REFERENCES}

Baines, Donna and Nandita Sharma. 2002. "Migrant Workers as Non-Citizens: The Case Against Citizenship as a Social Policy Concept." Studies in Political Economy 69: 75-107.

Baluarte, David C. 2006. "Inter-American Justice Comes to the Dominican Republic: An Island Shakes as Human Rights and Sovereignty Clash." Human Rights Brief 13 (2): $25-28,38$.

Bartlett, Lesley, Kiran Jayaram, and Gulin Bonhomme.2011. "State literacies and Inequality: Managing Haitian Immigrants in the Dominican Republic." International Journal of Educational Development 31: 587-595.

Bauder, Harald. 2008. "Citizenship as Capital: The Distinction of Migrant Labor."Alternatives 33:315-333.

Bolemaradd, I., Korteweg, A. and Yurdakul, G. 2008. "Citizenship and Immigration: Multiculturalism, Assimilation, and Challenges to the Nation-State." Annual Review of Sociology 34:153-179.

Berg, Bruce L. 009. Qualitative Research Methods for the Social Sciences ( $7^{\text {th }}$ Edition). Boston, MA: Allyn \& Bacon.

Bosniak, Linda. 2007. "Varieties of Citizenship.” Fordham Law Review 75(5): 24492453.

Candelario, Ginetta E. B. 2007. Black Behind in the Ears: Dominican Racial Identity from Museums to Beauty Shops. Durham, NC: Duke University Press

Centro Bonó. 2011. "Vidas Suspendidas.”Observatorio de Derechos Humanos. OctoberDecember 2011. Retrieved from Centro Bono in Santo Domingo, Dominican Republic

Centro de Formacion y Agraría (CEFASA) y Consultores Económicos Financieros y Organizacionales (CEFINOSA). 2012. Mano de Obra de Origen Haitiano a La Economía Dominicana. Santiago, Dominican Republic: Published with financial support from the European Union. 
Chery, Dady. 2013. "Dominican-Haitian Tensions: Wag the Dog or Prelude to Genocide?" RT.com. December 05.Retrieved December 14, 2013. http://rt.com/op-edge/dominican-haitian-tensions-genocide-703/

Chauvin, Sebastián and Blanca Garcés Mascareñas. 2012. "Beyond Informal Citizenship: The New Moral Economy of Migrant Illegality." International Political Sociology 6: 241-259.

Congreso Nacional. Ley de Inmigración, N 95. Ministerio de Interior y Policía 1939. Retrieved on April 10, 2013 http://www.comisionadodejusticia.gob.do/phocadownload/Biblioteca_Virtual/Mi gracion/Ley\%2095,\%20de\%20Inmigracion.pdf

Congreso Nacional. Ley N 279, Reglamento de Migración. Ministerio de Interior y Policía 1939. Retrieved on April 10, 2013 http://www.comisionadodejusticia.gob.do/phocadownload/Biblioteca_Virtual/Mi gracion/Decreto\%20279,\%20Reglamento\%20Ley\%20Migracion.pdf

Congreso Nacional. Ley General de Migración, No. 285-04. Ministerio de Interior y Policía 2004. Retrieved on March 15, 2013 http://www.mip.gob.do/Portals/0/docs/Marco_Legal_Transparencia/2013Actualiz acion/Ley\%20No.285-04\%20Migraci\%C3\%B3n.pdf

Congreso Nacional. Reglamento 631-11. Ministerio de Interior y Policía 2011. Retrieved March 13, 2013 http://mip.gob.do/Portals/0/docs/proyectosdeley/DEC_NO_63111REGLAMENTOLEYDEMIGRACION.pdf

Cornelisse, Galina. 2010. "Immigration Detention and thee Territoriality of Universal Human Rights" Pp 101-122 in Deportation Regime, edited by Nathalie Peutz and Nicolas DeGenova. Durham, NC: Duke University Press.

Corten, Andre, Isis Duarte, Consuelo M. Soto, and Viviana Fridman.1995. "Five Hundred Thousand Haitians in the Dominican Repbulic." Latin American Perspectives 22(3):94-110.

DeGenova, Nicholas. 2002. "Migrant "Illegality" and Deportability in Everyday Life." Annual Review of Anthropology 31: 419-47.

DeGenova, Nicholas. 2004. "The Legal Production of Mexican/Migrant "Illegality"” Latino Studies 2: 160-185

DeGenova, Nicholas. 2010. "The Deportation Regime: Sovereignty, Space, and the Freedom of Movement." Pp. 33-68 in Deportation Regime. Durham, NC: Duke University Press.

DeGenova, Nicholas. 2013. "Spectacles of migrant 'illegality': the scene of exclusion, the obscene of inclusion." Ethnic and Racial Studies 36(7): 1180-1198. 
Donato, Katharine M. and Armenta, Amada. 2011. "What We Know About Unauthorized Migration." Annual Review of Sociology 37: 529-543.

Frontán, Manuel. 2013. “Se Habla de un Pacto Para el 2016 Entre Danilo y Leonel.” El Caribe, December, 12. Retrieved on December 14, 2013.http://www.elcaribe.com.do/2013/12/09/habla-pacto-para-2016-entredanilo-leonel

Giddens, Anthony. 1976. New Rules of Sociological Method: A Positive Critique of Interpretative Sociologies. New York, NY: Basic Books, Inc., Publishers.

Howard, David. 2001. Coloring the Nation: Race and Ethnicity in the Dominican Republic. Oxford, UK: Signal Books.

Howard, David.2007. "Development, Racism, and Discrimination in the Dominican Republic.” Development in Practice 17(6): 725-738.

Isin, Engin F and Bryan s. Turner. 2002. Citizenship Studies: An Introduction. Pp.1-10 in Isin, Engin F. and Turner, Bryan S. eds. Handbook of citizenship studies. London UK: Sage.

Karakayali, Serhat and Enrica Rigo. 2010. "Mapping the Space of European Space of Circulation." Pp. 123-147 in Deportation Regime, edited by Nathalie Peutz and Nicolas DeGenova. Durham, NC: Duke University Press.

Kosinski, Stacie. 2009. "State of Uncertainty: Citizenship, Statelessness and Discrimination in the Dominican Republic." Boston College International and Comparative Law Review 32 (2): 377-398.

Mathae, Lauren. 2011. "From Haiti to the Dominican Republic and Back: Disjunctive Pattern of Immigration on Hispaniola in the Aftermath of the Haitian Earthquake." Center for Hemispheric Affairs. Accessed on May 12, 2012 (http://www.coha.org/from-haiti-to-the-dominican-republic-and-back/).

Martin, Philip, Elizabeth Midgley, and Michael S. Teitelbaum.2002. "Migration and Development: Whither the Dominican Republic and Haiti?" International Migration Review 36(2): 570-592.

Martinez, Samuel. 1999. "From Hidden Hand to Heavy Hand: Sugar, the State, and Migrant Labor in Haiti and the Dominican Republic." Latin Research Review 34(1): 57-84.

Martinez, Samuel. 2003. "Not a Cockfight: Rethinking Haitian-Dominican Relations." Latin American Perspectives 30(3): 80-101

Meacham, Carl. 2013. The Dominican Republic Becoming a One Party State. A Report of the CSIS Program in the Americas, Center for Strategic and International Studies. Landham, MD. Also available at https://csis.org/files/publication/131111_Meacham_DominicanRepublic_Web.pdf 
Moya Pons, Frank.1995. The Dominican Republic: A National History. New Rochelle, NY: Hispaniola Books.

Myers, M. D. 1997. "Qualitative Research in Information Systems," Management Information Systems Quarterly 21(2):241-242.

Oficina Nacional de Estadística. La Primera Encuesta Nacional de Inmigrantes en la Republica Dominicana (ENI). 2012. Santo Domingo, Dominican Republic: Oficina Nacional de Estadística Retrieved March 15, 2013 http://www.one.gob.do/var/uploads/File/ENI\%202012/Informe\%20General\%20P rimera\%20Encuesta\%20Nacional\%20de\%20Inmigrantes\%20en\%20RDENI\%202012.pdf

Open Society Foundation. 2010. "Dominicans of Haitian Descent and the Compromised Right to Nationality." Report presented to the Inter-American Commission on Human Rights on the Occasion of its $140^{\text {th }}$ Session on October 2010.

Open Society Justice Initiative. 2009. "Discrimination in Access to Nationality: statement Submitted for Consideration by the United Nations." Human Rights Council at its 6th session

Patterson, Michael E. and Daniel R. Williams. 2002. Collecting and Analyzing Qualitative Data: Hermeneutic Principle, Methods, and Case Examples. Champaign, IL: Sagamore Publishing.

Payne, Geoff and Judy Payne. 2004. Key Concepts in Social Research. Thousand Oaks, CA: Sage

Peutz, Nathalie and Nicholas DeGenova. 2010. "Introduction". Pp 13 -33 in Deportation Regime, edited by Nathalie Peutz and Nicolas DeGenova. Durham, NC: Duke University Press

Portes, Alejandro. 1978. "Introduction: Toward a Structural Analysis of Illegal (Undocumented) Immigration." International Migration Review 12(4) 469-484

Rosario, Reina and Jorge Ulloa. 2006. "Algunos Aspectos Socioculturales de la Inmigración Haitiana Hacia la República Dominicana." Ciencia y Sociedad 23(1): 64-124

Sagás, Ernesto. 2000. Race and Politics in the Dominican Republic. Gainesville,FL: University Press of Florida.

Sandelowski, Margarete. 2000. "Focus on Research Methods: Whatever happened to Qualitative Description." Research in Nursing and Health 23: 334-340

Sharma, Nandita. 2012. "The "Difference" that Borders Make: "Temporary Foreign Workers" and the Social Organization of Freedom in Canada" in Legislated Inequality: temporary Labour Migration in Canaada. Edited by Patti Tamara Lenard and Christine Straehle. McGill-Queen's University Press - Canada. 
Sillié, Rubén. 2005. “Aspectos y variables de las relaciones entre República Dominicana y Haití." Revistas Futuro 9(3): http://www.revistafuturos.info.

Teff, Melanie and Marselha Gonclaves Margenin. 2008. "Dominican Republic: Time to Move Forward to Resolve Statelessness." Refugees International. May, 07,2012 (http://www.refugeesinternational.org/policy/field-report/dominican-republictime-move-forward-resolve-statelessness).

Torres-Saillant. 2000. "The Tribulations of Blackness: Stages in Dominican Racial Identity." Callaloo 23(3): 1086-1111.

Tribunal Constitucional, Repbulica Dominicana. Sentencia TC/0168/13. Tribunal Constitucional 2013. Retrived October 13,203 http://tribunalconstitucional.gob.do/node/1764.

Turits, Richard Lee. 2002. "A World Destroyed a Nation Imposed: The 1937 Haitian Massacre in the Dominican Republic." Hispanic American Historical Review 82(3):589-635.

Wooding, Bridget. 2008. "Contesting Dominican Discrimination and Statelessness." Peace Review: A Journal of Social Justice 20(3):366-375.

Wooding, Bridget and Richard Moseley-Williams. 2004. Needed but Unwanted: Haitian Immigrants and Their Descendants in the Dominican Republic. London, UK: Catholic Institute for International Relations.

World Bank. 2012. "Haiti Overview." Washington, DC: World Bank. Retrieved April 30, 2013 http://www.worldbank.org/en/country/haiti/overview.

Wucker, Michelle. 1999. Why the Cocks Fight: Dominicans, Haitians, and the Struggle for Hispanola. New York, NY: Hill and Wang. 